
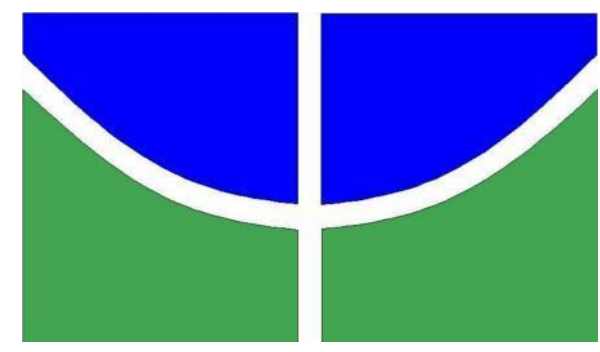

Universidade de Brasília (UnB)

Faculdade de Economia, Administração

e Contabilidade (FACE)

Departamento de Economia (ECO)

Programa de Pós-Graduação em Economia

Mestrado Profissional em Economia

FRANCINILDA OLIVEIRA BARBOSA

AVALIAÇÃO DO SISTEMA IMOBILIÁRIO DA FUB COMO CONTRIBUIÇÃO ECONÔMICO-FINANCEIRA PARA A UNIVERSIDADE 
FRANCINILDA OLIVEIRA BARBOSA

\section{AVALIAÇÃO DO SISTEMA IMOBILIÁRIO DA FUB COMO CONTRIBUIÇÃO ECONÔMICO-FINANCEIRA PARA A UNIVERSIDADE}

Dissertação apresentada ao Programa de Pós-Graduação em Economia - PPGE - da Faculdade de Administração, Contabilidade e Economia (FACE) da Universidade de Brasília (UnB), como requisito parcial à obtenção do título de Mestre em Economia.

Orientadora: Prof. Dra. Andrea Felippe Cabello 
FRANCINILDA OLIVEIRA BARBOSA

\section{AVALIAÇÃO DO SISTEMA IMOBILIÁRIO DA FUB COMO CONTRIBUIÇÃO ECONÔMICO-FINANCEIRA PARA A UNIVERSIDADE}

Dissertação aprovada como requisito para a obtenção do título de Mestre em Economia do Programa de Pós-Graduação em Economia do Departamento de Economia da Universidade de Brasília (ECO/UnB), que foi avaliada e aprovada pela Comissão Examinadora formada pelos professores:

Prof. Dra. Andrea Felippe Cabello - Orientadora

Departamento de Economia - UnB

Prof. Dr. Jorge Madeira Nogueira

Departame5to de Economia - UnB

Prof. Dr. Antônio Nascimento Júnior

Departamento de Administração - UnB

Brasília, 5 de agosto de 2015. 
Dedico a Deus, pela oportunidade dessa caminhada e por ser sempre fonte inesgotável de sabedoria e paz.

Ao meu querido pai, Francisco Madeira, pela inspiração de entusiasmo e entrega em tudo que faz;

À minha querida mãe, Maria Zenilda, pelo exemplo de amor e dedicação;

Ao meu marido, Marcus Vinícius, pela compreensão, torcida e apoio incondicional para que eu lutasse pelos meus objetivos;

Às minhas filhas, Louise Catherine e Rafaela Sophie, amores da minha vida. 


\section{AGRADECIMENTOS}

Agradeço à minha família e a todos os que me apoiaram durante a realização deste estudo;

À Professora Andrea Cabello, pelos conselhos e orientações imprescindíveis à realização deste trabalho;

À minha colega Ana Rachel, pela ajuda nos momentos mais críticos e em todo o decorrer do curso;

Aos colegas da Coordenação de Execução Contábil e Diretoria de Contabilidade e Finanças - DCF, pelo apoio durante a jornada;

Aos funcionários da Secretaria de Gestão Patrimonial - SGP, pela atenção e presteza. 
A tarefa não é tanto ver aquilo que ninguém viu, mas pensar o que ninguém ainda pensou sobre aquilo que todo mundo vê.

Arthur Schopenhauer 


\section{RESUMO}

Este estudo tem o objetivo de avaliar o sistema imobiliário da FUB como contribuição econômico-financeira para a Universidade, tendo em vista o desafio de administrar um recurso escasso com muitas demandas. Para a concretização da pesquisa, foram detalhadas as informações das variáveis relativas ao sistema imobiliário, adotadas pela FUB e utilizadas no mercado. O estudo evidencia renúncia de receita e o custo da atividade imobiliária, além de trazer uma reflexão sobre o custo de oportunidade aplicado aos recursos provenientes dos imóveis da FUB. Revela um pequeno percentual de servidores beneficiados com o subsídio de moradia, bem como as variáveis que dificultam o acesso de novos servidores aos imóveis da FUB. Mostra a existência do ótimo de Pareto e apresenta duas hipóteses que podem resultar em complementação de renda ao corpo funcional.

Palavras-Chave: Ótimo de Pareto. Renúncia de receita. Custo de oportunidade. Patrimônio imobiliário. Receita sacrificada. 


\begin{abstract}
This study aims to evaluate the realty system at the University of Brasilia in its budget system, given its challenge to manage its scarce resources. We detailed information on the relevant variables adopted by the university and the market. The study shows the many subsidies and the costs imposed on the university and brings a reflection on the opportunity cost of such an activity. It also shows that only a small number of employees are contemplated and that new employees face a entry barrier. It deals with Pareto efficiency issues and presents two hypothesis regarding income complementation to its faculty.
\end{abstract}

Keywords: Pareto efficiency. Revenue disclaimer. Opportunity cost. Real estate assets. Revenue sacrificed. 


\section{LISTA DE FIGURAS}

Figura 01: Demonstrativo da ocupação dos Imóveis funcionais (Termo de Ocupação) divididos por categorias.

Figura 02: Tempo de ocupação dos imóveis por Termo de Ocupação em anos agrupados por faixa de 10 anos.

Figura 03: Demonstrativo da distribuição dos Imóveis alugados (SGP) agrupados por categorias Terceiros (Público externo à FUB/UnB) e Servidores da FUB/UnB (aluguel com $20 \%$ de desconto).

Figura 04: Despesa com manutenção e reforma em relação à receita realizada valores nominais/porcentagem

Figura 05: Representatividade da despesa com pessoal, serviços e material Valores Nominais/Porcentagem

Figura 06: Representatividade da despesa total em relação à receita realizada Valores Nominais/Porcentagem.

Figura 07: Representatividade das despesas de atividades imobiliárias no orçamento da FUB - valores nominais.

Figura 08: Receita realizada em relação ao orçamento da FUB - valores nominais 43

Figura 09: Diferença entre o aluguel adotado pela FUB e o aluguel valor de mercado - exercício 2009

Figura 10: Diferença entre o aluguel adotado pela FUB e o aluguel valor de mercado - exercício 2010

Figura 11: Diferença entre o aluguel adotado pela FUB e o aluguel valor de mercado - exercício 2011.

Figura 12: Diferença entre o aluguel adotado pela FUB e o aluguel valor de mercado - exercício 2012

Figura 13: Diferença entre o aluguel adotado pela FUB e o aluguel valor de mercado - exercício 2013.

Figura 14: Representação da receita potencial em relação à dotação orçamentária

Figura 15: Potencial receita de rendimento da poupança em relação a receita de aluguel realizada

Figura 16: Representatividade do potencial rendimento da poupança em relação ao orçamento da FUB

Figura 17: Percentual de servidores contemplados com o benefício .64

Figura 18: Quantidade de servidores subsidiados e não-subsidiados 64 


\section{LISTA DE QUADROS}

Quadro 01: Etapas, objetivos e instrumentos de pesquisa. 27

Quadro 02: Descrição da Construção das formas alternativas de gestão de patrimônio .30

\section{LISTA DE TABELAS}

Tabela 01: Receita e despesa da atividade imobiliária - valores nominais...............32

Tabela 02: Despesa com manutenção e reformas - valores nominais......................33

Tabela 03: Despesa para manutenção dos imóveis - valores nominais ...................34

Tabela 04: Detalhamento das despesas para manutenção e conservação dos

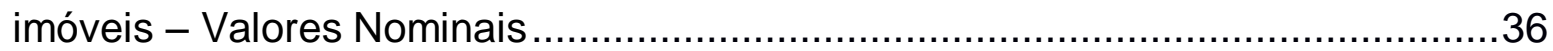

Tabela 05: Taxa de ocupação sem reajuste - valores nominais: ...........................37

Tabela 06: Receita do termo de ocupação sem atualização dos valores - Valores

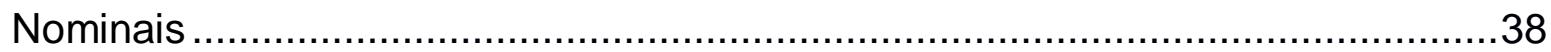

Tabela 07: Receita do termo de ocupação corrigido pelo IGP-M (FGV) de 2005 a

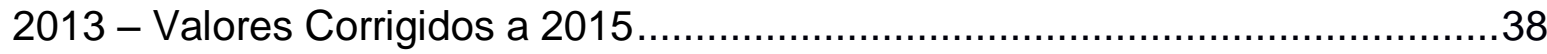

Tabela 08: Total da renúncia de receita - Comparação de Valores Corrigidos e Não

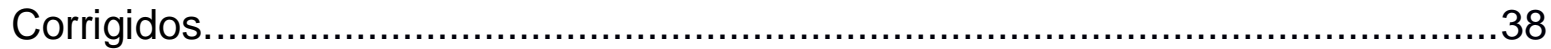

Tabela 09: Divisão da ocupação dos imóveis residenciais .....................................39

Tabela 10: Inadimplência dos imóveis da FUB - valores nominais ..........................41

Tabela 11: Execução orçamentária da FUB - valores nominais.............................42

Tabela 12: Média do aluguel adotado pela FUB - valores nominais ......................44

Tabela 13: Imóveis residenciais destinados à moradia de servidores ......................47

Tabela 14: Diferença do aluguel adotado pela FUB e aluguel de mercado - Em

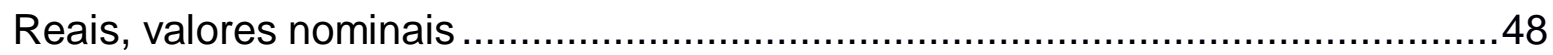

Tabela 15: Valor de metro quadrado de locação e de venda ................................53

Tabela 16: Receita de aluguel potencial dos imóveis da FUB - 2009 .....................54

Tabela 17: Receita de aluguel potencial dos imóveis da FUB -2010 .....................54

Tabela 18: Receita de aluguel potencial dos imóveis da FUB $-2011 \ldots \ldots \ldots \ldots \ldots \ldots \ldots . . .55$

Tabela 19: Receita de aluguel potencial dos imóveis da FUB -2012 .....................55

Tabela 20: Receita de aluguel potencial dos imóveis da FUB $-2013 \ldots \ldots \ldots \ldots \ldots \ldots \ldots . . .55$

Tabela 21: Receita sacrificada - Alternativa A …….........................................56

Tabela 22: Complemento de renda dos servidores da FUB - Alternativa A .............57

Tabela 23: Média do valor do subsídio aos servidores beneficiados ........................58

Tabela 24: Rendimento da poupança ..............................................................6

Tabela 25: Valor de complemento de renda dos servidores da FUB -

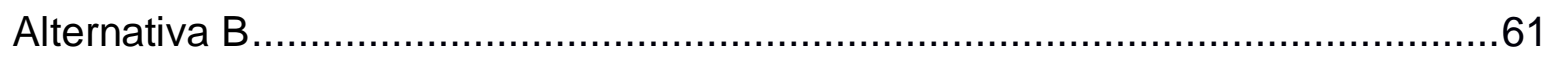

Tabela 26: Receita sacrificada em comparação ao potencial rendimento da poupança 


\section{LISTA DE ABREVIATURAS}

FUB $\quad$ Fundação Universidade de Brasília.

IFES Instituições Federais de Ensino Superior.

LDO Lei de Diretrizes Orçamentárias.

LOA Lei Orçamentária Anual.

LRF Lei de Responsabilidade Fiscal.

PNR Próprio Nacional Residencial.

$\mathrm{R} \$ \quad$ Reais.

SECOVI-DF Sindicato Habitacional do Distrito Federal.

SGP Secretaria de Gestão Patrimonial.

SIAFI Sistema de Administração Financeira.

SpiuNet Sistema de Gerenciamento dos Imóveis de Uso Especial da União.

STN Secretaria do Tesouro Nacional.

UFRJ Universidade Federal do Rio de Janeiro.

UnB Universidade de Brasília. 


\section{SUMÁRIO}

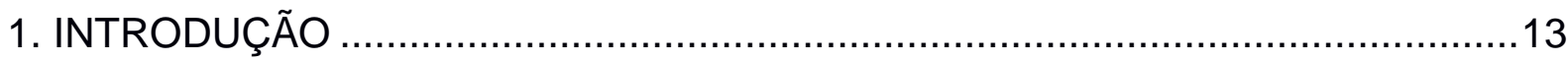

1.1 Contextualização e Formulação do Problema ...............................................13

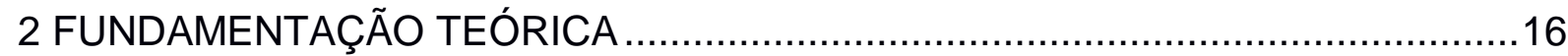

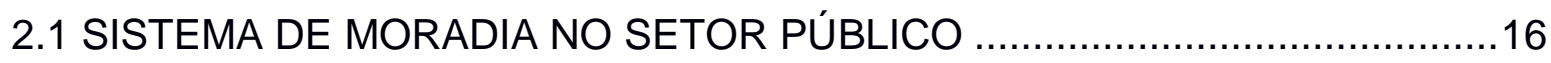

2.2 FORMAS DE OCUPAÇÃO DOS IMÓVEIS DA FUB:......................................19

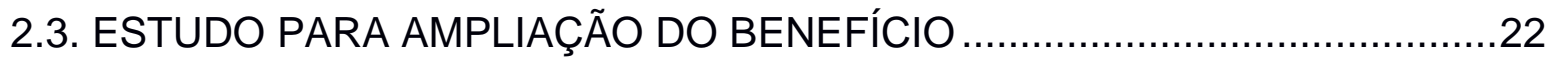

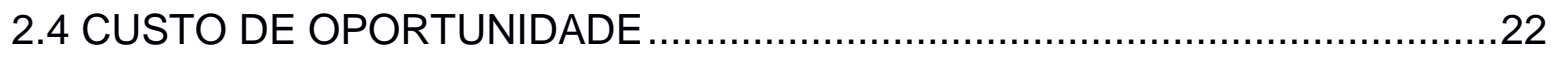

2.5 ECONOMIA NORMATIVA E ECONOMIA POSITIVA ….............................23

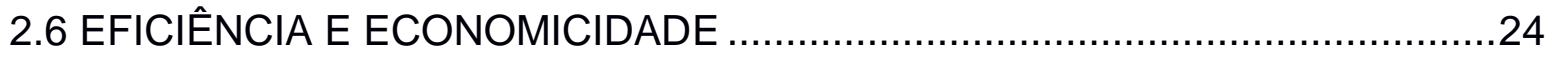

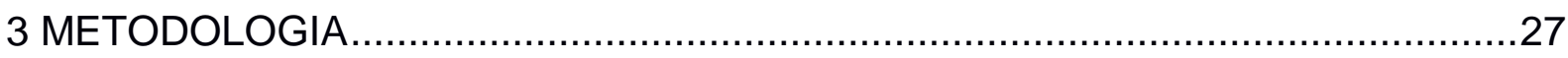

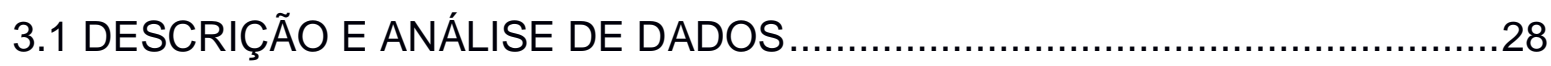

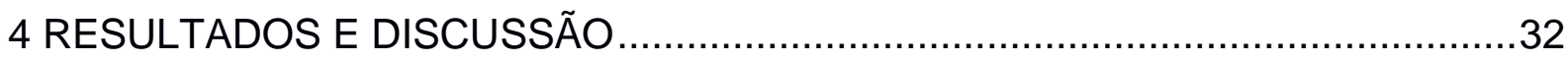

4.1 RECEITAS E DESPESAS RESULTANTES DA ATIVIDADE IMOBILIÁRIA E

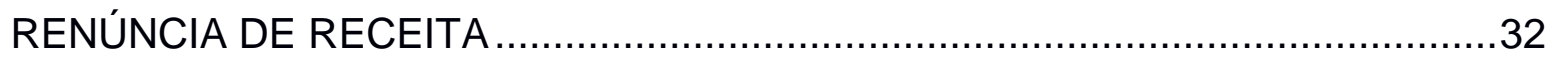

4.1.1 Receitas e Despesas resultantes da atividade imobiliária .........................32

4.1.2 Despesa com manutenção e reforma dos imóveis - 2009 a 2013 .............34

4.1.3 Despesa com pessoal, limpeza, material de consumo e serviços ...............35

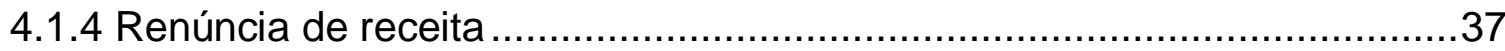

4.2 REPRESENTAÇÃO DA INADIMPLÊNCIA DOS ALUGUÉIS DOS IMÓVEIS DA

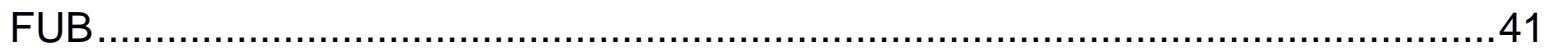

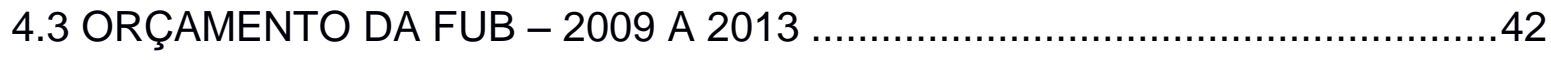

4.4 ESTUDO DO CUSTO DE OPORTUNIDADE..............................................4

4.4.1 Receita proveniente dos aluguéis adotados pela FUB - 2009 a $2013 \ldots \ldots . .45$

4.4.2 Valor do aluguel de mercado: ...............................................................

4.4.3 Análises de alternativas da gestão do patrimônio imobiliário......................53

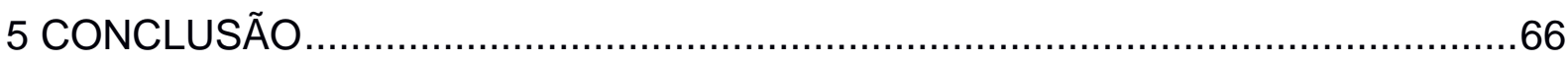

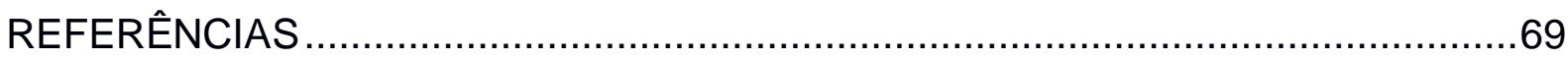




\section{INTRODUÇÃO}

\subsection{CONTEXTUALIZAÇÃO E FORMULAÇÃO DO PROBLEMA}

A Universidade de Brasília (UnB), historicamente, distingue-se das demais Instituições Federais de Ensino Superior (IFES) por possuir terrenos obtidos com sua criação, razão pela qual tornou-se a proprietária de um composto imobiliário importante na capital do país. Das 64 universidades federais do Brasil mantidas pela União a partir de recursos do Ministério da Educação, a UnB é a instituição com o segundo maior orçamento, ficando atrás somente da Universidade Federal do Rio de Janeiro (UFRJ). Desde a sua criação, a UnB tem um papel extremamente importante, tanto nacional quanto regional, no que diz respeito à excelência do ensino e da pesquisa. Atualmente, é a maior instituição de ensino superior do Centro-Oeste do Brasil e uma das mais importantes do país.

A Fundação Universidade de Brasília (FUB) destaca-se entre as instituições públicas do país no que diz respeito ao autofinanciamento e ao total da despesa. A UnB possui a maior proporção de gasto com recurso diretamente arrecadado, dentre as universidades públicas e as IFES (VELLOSO; MARQUES, 2005, p. 655-680).

A UnB tem uma história singular entre as demais universidades, ela foi criada logo após a inauguração de Brasília, com a intenção de transformar a educação superior, unir as diversas formas do saber e formar profissionais participativos na transformação do país. O patrimônio inicial da Fundação compreendeu vários bens e direitos, como terrenos em doze superquadras urbanas em Brasília, doados pela Companhia Urbanizadora da Nova Capital.

Hoje, a UnB dispõe de quatro campi nas cidades de Brasília (Campus Darcy Ribeiro), Planaltina (Faculdade UnB Planaltina), Gama (Faculdade UnB Gama), Ceilândia (Faculdade UnB Ceilândia) e Paranoá (em projeto). A área total dos 4 campi é de 4.787.449,13 m², sendo que o principal, Darcy Ribeiro, tem 3.950.569,07 $\mathrm{m}^{2}$.

A FUB possui 1.745 imóveis, unidades de salas, lojas, apartamentos, terrenos e garagens. Sua Secretaria de Gestão Patrimonial (SGP) administra uma carteira imobiliária composta de 1.690 imóveis, conforme o Relatório de Gestão 2013 do Decanato de Planejamento e Orçamento (DGP). Todos os imóveis estão cadastrados no Sistema de Gerenciamento dos Imóveis de Uso Especial da União - 
SpiuNet. Segundo os dados do Inventário Patrimonial de Imóveis da Fundação Universidade de Brasília, Ano Base 2012, a ocupação dos imóveis residenciais está assentada em duas políticas distintas, uma voltada para moradia destinada a servidores da instituição, regulamentada e definida pela Resolução do Conselho Diretor FUB no 30/2004, e outra direcionada ao mercado imobiliário.

A presente pesquisa pretende avaliar o sistema imobiliário da FUB e verificar qual a contribuição econômico-financeira desse sistema para a universidade e responder à seguinte pergunta: qual a contribuição econômico-financeira do Sistema Imobiliário da FUB para a Universidade?

O objetivo geral deste trabalho é avaliar a contribuição econômico-financeira do Sistema Imobiliário da FUB aplicada na Universidade, a fim de investigar maneiras alternativa para alocação dos imóveis visando a ampliação do número de beneficiários à moradia. No mesmo sentido, o estudo pretende também evidenciar as despesas operacionais inerentes à atividade imobiliária e trazer uma reflexão sobre o custo de oportunidade dos recursos provenientes da FUB, que poderão servir de informações para a tomada de decisão dos gestores na alocação eficiente dos recursos.

A fim de atingir o objetivo geral, foram estabelecidos objetivos específicos tais como:

a) levantar o valor de aluguel pago pelos ocupantes de cada unidade para saber a receita atual;

b) avaliar quanto a FUB tem a receber em relação à dívida de inadimplentes;

c) levantar as despesas com limpeza, zeladoria, elevadores, pessoal e material;

d) avaliar quanto a FUB gasta com materiais em reformas de infraestrutura para manter os imóveis em condições de uso;

e) verificar a representatividade, no orçamento da FUB, das despesas com atividades imobiliárias;

f) comparar a receita com a despesa, resultantes das atividades imobiliárias;

g) levantar o valor de mercado de cada unidade (metro quadrado médio);

h) levantar o custo de oportunidade de recurso despendido;

Este trabalho está organizado em cinco capítulos, incluindo esta introdução. No capítulo dois é apresentado o referencial teórico que abrange as políticas de moradias de órgãos semelhantes à UnB; os efeitos da existência do auxílio moradia 
sobre o mercado de trabalho; e, por último, a ideia de eficiência de Pareto e KaldorHicks e o custo de oportunidade. O capítulo três detalha a metodologia utilizada no trabalho. O capítulo quatro analisa, no período estudado, a evidenciação e aplicação dos resultados e as conclusões finais são descritas no capítulo cinco. 


\section{FUNDAMENTAÇÃO TEÓRICA}

\subsection{SISTEMA DE MORADIA NO SETOR PÚBLICO}

As Políticas Públicas podem ser compreendidas como um sistema, um conjunto de elementos que se interligam, com vistas ao cumprimento de um fim: o bem-comum da população a quem se destinam, ou mesmo como um processo, pois tem ritos e passos, encadeados, objetivando uma finalidade (FARIA, 2009, p.39).

A Universidade de Brasília se diferencia das demais instituições de ensino superior, pois foi construída em uma cidade que não tinha pessoas suficientes para preencher o quadro de docentes e servidores. Para atender a esse propósito, houve a necessidade de construir moradias dentro da Universidade, tanto para os discentes quanto para os docentes vindos de outros estados. As moradias seriam um benefício, por meio de salário indireto, além de facilitarem a mobilidade numa cidade incipiente.

Para Villaça, por exemplo, "o aglomerado urbano compreende um núcleo que "apresenta um mínimo de atividades centrais, sejam religiosas, administrativas, políticas, sociais ou econômicas". (VILLAÇA, 2001, p. 52).

As cidades, principalmente as maiores, oferecem facilidades para as pessoas, baseadas nos ganhos de escala para os cidadãos, como moradia, saúde e educação, o que possibilitou que elas se tornassem a escolha racional dos agentes econômicos (LAMPARD, 1955).

Ainda que as cidades apresentem diversas vantagens - forças de atração -, como moradia, educação, salários, mercado e facilidade de serviços públicos, também possuem vários fatores de repulsão - forças centrífugas. Deve-se admitir que a vida nos centros urbanos não apresenta apenas benefícios, mas também diversas desvantagens, como congestionamento, poluição, criminalidade, fenômenos que ocorrem nas cidades modernas (VERHOEF e NIJNAMP, 2003).

Hoje Brasília é considerada uma metrópole nacional e, de acordo com a classificação das regiões metropolitanas realizada pelo IBGE, possui o terceiro maior PIB do país e é a quarta região mais populosa do Brasil. Por sua vez, a Universidade de Brasília é apontada como a melhor do Centro-Oeste e a oitava mais bem avaliada do país, segundo o Ranking Universitário Folha (RUF), publicado em 8/9/2014. Mas, 
tratando-se da política salarial para os servidores, a fundação é dependente da Lei 8.112/1990, o regime jurídico dos servidores públicos civis da União, das autarquias e das fundações públicas federais. Assim, a Universidade deve buscar oferecer, aos seus recursos humanos, vantagens salariais indiretas, tais como: moradia, plano de saúde, manutenção da Unidade de Referência de Preços - URP, creche, clube, a fim de garantir a permanência do corpo funcional, tendo em vista as ofertas atrativas no mercado e até mesmo em outros cargos nos quadros do serviço público.

As universidades do interior do país, por sua vez, são mais atrativas em relação ao poder de compra do salário, tendo em vista as facilidades encontradas nas pequenas cidades, tais como: preços dos imóveis, proximidade de casa para o trabalho, ausência de trânsito, economia em combustível, menor índice de criminalidade e consequente alto poder de compra, aumento do salário real e qualidade de vida.

A UnB, para atrair quadros de excelência e manter a competitividade no mercado de trabalho, oferece o benefício indireto da moradia. A instituição criou o Regulamento de Ocupação e Manutenção dos Imóveis Residenciais da FUB destinados à moradia dos seus servidores. A exemplo da UnB, outras instituições, tanto no Brasil quanto no exterior, possuem realidades semelhantes quanto à utilização do benefício de moradia para atrair profissionais.

A Câmara dos Deputados, por exemplo, dispõe de 432 apartamentos. Segundo dados de fevereiro de 2014, 297 parlamentares ocupam apartamentos funcionais. Nos últimos quatro anos, os gastos com manutenção do conjunto de imóveis foram em média de $\mathrm{R} \$ 7,5$ milhões ao ano - o equivalente a um custo mensal de $\mathrm{R} \$ 2.200,00$ por deputado ocupante. As despesas devem baixar em cerca de $\mathrm{R} \$ 316,8$ mil por mês com a conclusão da reforma e o aumento da ocupação dos apartamentos funcionais (CÂMARA DOS DEPUTADOS, 2014).

O Exército Brasileiro dispõe de 18.549 moradias funcionais (Próprio Nacional Residencial - PNR), além de todo o seu ativo imobiliário composto por quartéis, fazendas, terrenos, hotéis de trânsito, escritórios etc. Como definido em Portaria 277/2008, o PNR "é a edificação, de qualquer natureza, utilizada com a finalidade específica de servir de residência para os militares da ativa do Exército".

Os militares que ocupam um PNR são chamados de "permissionários" e, para o usufruto de uma dessas unidades residenciais, pagam mensalmente uma taxa correspondente a $5 \%$ do soldo, descontada diretamente dos vencimentos. Esse 
pagamento denomina-se "taxa de uso". Do valor arrecadado com a "taxa de uso", $30 \%$ são retidos e aplicados no Fundo do Exército e $70 \%$ voltam diretamente para a organização militar de origem. Esses recursos são utilizados para a manutenção dos PNRs e das áreas comuns, incluindo instalação de cercas, muros e câmeras de segurança, como também para a pintura geral, que acontece a cada dois anos, mantendo os PNRs em satisfatório estado de conservação e limpeza (BONATES e VALENÇA, 2010).

Além dessas, há a experiência internacional realizada pelo Instituto Cidades de Grande (GCl), da Universidade de llinois, Chicago, Estados Unidos, para o Lincoln Institute of Land Policy, que explora programas de moradia para atender às necessidades das universidades (Employer Assisted Housing Program - Programa EAH). Para a análise, os autores utilizaram 22 programas de moradia aplicados em três estudos de caso, (Case Western Reserve University, University of Chicago e Howard University), identificando as motivações para modelos comuns para empregadores universitários.

A análise dos estudos de caso revela que o Programa EAH pode ser uma forma eficaz para as universidades abordarem a falta de moradias para seus funcionários. A confiança entre as universidades e as comunidades vizinhas é identificada como um fator-chave na limitação ou melhora dos resultados de desenvolvimento comunitário de universidades do Programa EAH. Uma lição geral que emerge dessa pesquisa é que o Programa EAH pode ser uma maneira eficaz para universidades lidarem com a falta de moradia para seus empregados ou de um segmento específico de seus funcionários.

A análise mostra que o programa pode ser uma boa ferramenta para a universidade ajudar a fornecer ou diminuir o custo de habitação para os seus funcionários de uma maneira direta. Ofertar os benefícios financeiros que fazem parte do modelo de parceiro financeiro é uma das formas menos dispendiosas para as universidades fornecerem assistência habitacional aos seus empregados, geralmente por meio de subsídios ao financiamento imobiliário.

O caso de sucesso da Universidade de Chicago, ao ajudar os seus 105 funcionários a se tornarem proprietários de casas em comunidades vizinhas em menos de três anos oferece a evidência da utilidade do Programa EAH, quando encontra os parceiros certos e são ofertados os tipos certos de assistência. Mostra como um programa desse tipo pode efetivamente atingir os objetivos da 
universidade em relação a recrutamento e retenção de pessoal (HOERETH; PACKNETT; PERRY, 2007). Em comparação à FUB, não apresenta uma política de moradia objetiva e clara aos servidores, com isso beneficia poucos em detrimento de muitos.

Pela exposição, torna-se clara uma reflexão sobre a clareza de objetivos e eficiência no papel da FUB ao oferecer esse tipo de serviço para seus docentes e técnicos, com o intuito de atrair e manter profissionais qualificados na instituição.

\subsection{FORMAS DE OCUPAÇÃO DOS IMÓVEIS DA FUB:}

A Resolução N. 30/Conselho Diretor da FUB/2004 diz que a ocupação dos imóveis por servidores ocorre em estrita obediência à ordem de classificação da lista elaborada pela Comissão Especial de Moradia - CEM. Segundo a resolução:

a) O Termo de Ocupação terá validade de um ano, podendo ser renovado a critério exclusivo da FUB, enquanto o servidor mantiver vínculo empregatício com a Instituição.

b) A ocupação de imóveis por servidores extraquadro será condicionada à manutenção de vínculo com a UnB por, pelo menos, 6 (seis) meses posteriores à data da assinatura do Termo de Ocupação.

c) A Reserva Técnica de imóveis residenciais, administrada exclusivamente pelo Reitor da UnB, visando a atender aos interesses estratégicos da Fundação Universidade de Brasília, é destinada ao incentivo e à atração de pessoal de alto nível de qualificação, podendo contemplar o Professor Visitante e colaboradores diretos da Administração Superior, selecionados pela UnB para fortalecer e manter o seu quadro docente e funcional, cumprindo-se as demais normas deste Regulamento.

d) Na hipótese de afastamento com ônus do titular de Termo de Ocupação, será concedida, exclusivamente a servidor da FUB, autorização para ocupação temporária de imóvel residencial, mediante solicitação formal do ocupante.

Conforme o Relatório da I Audiência Pública sobre Política de Moradia da UnB, realizada em 9 de abril de 2013, dos imóveis próprios ocupados na condição de Termo de Ocupação, aproximadamente $66 \%$ atendem aos docentes ativos do 
quadro e $30 \%$ aos servidores técnicos administrativos, como demonstra a Figura 1.

Figura 01: Demonstrativo da ocupação dos Imóveis funcionais (Termo de Ocupação) divididos por categorias.

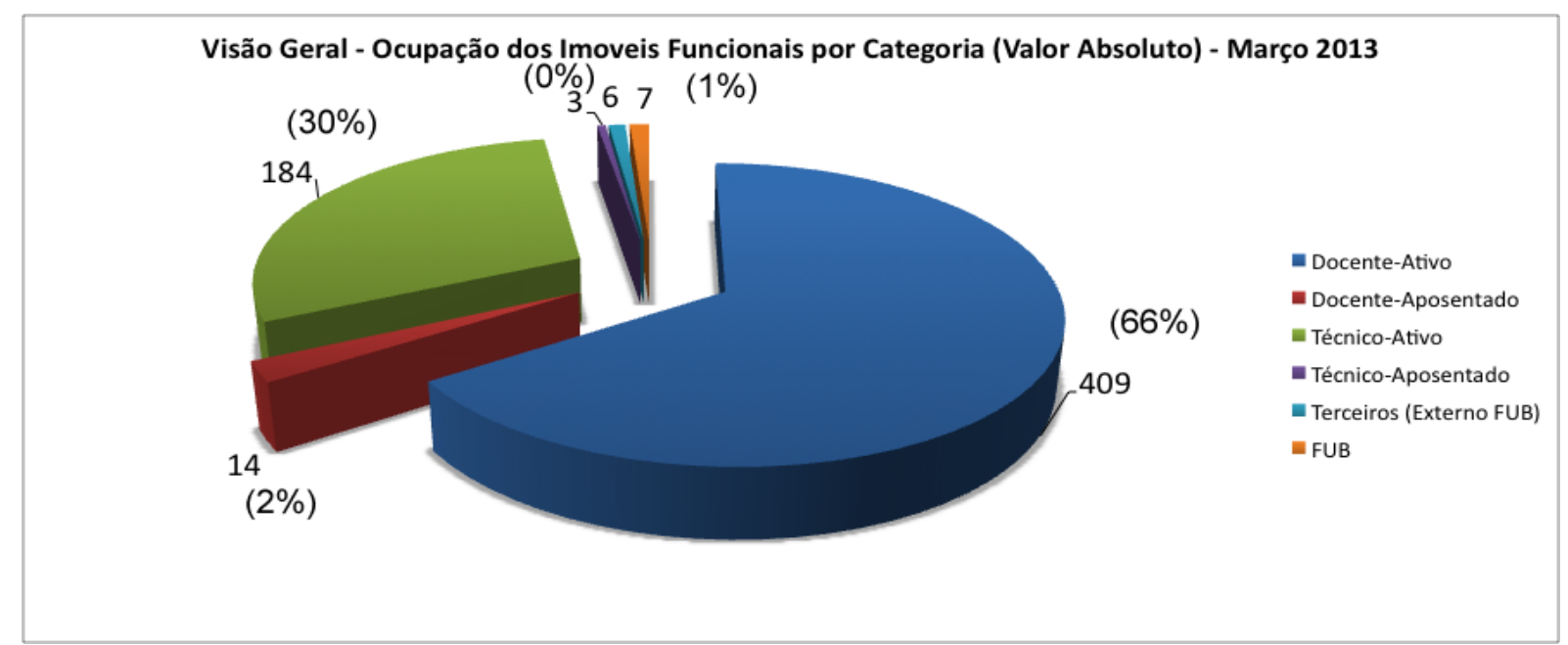

Fonte: Relatório da I Audiência Pública sobre Política de Moradia da UnB, 2013.

A Resolução do Conselho de Administração 2/1999 dizia que O Termo de Ocupação teria validade de um ano, podendo ser renovado pelo prazo máximo de sete anos, no entanto a Resolução do Conselho Diretor 30/2004, revogou a Resolução CAD 2/1999 e não limitou tempo para ocupação do imóvel, o que dificulta o acesso a outros servidores. Ainda, conforme dados do mesmo relatório:

- De 11 a 20 anos, corresponde a uma parcela de $30 \%$ dos ocupantes;

- De 21 a 30 anos, corresponde a 11\% dos ocupantes, divididos entre docentes e técnicos administrativos.

Figura 02: Tempo de ocupação dos imóveis por Termo de Ocupação em anos agrupados por faixa de 10 anos

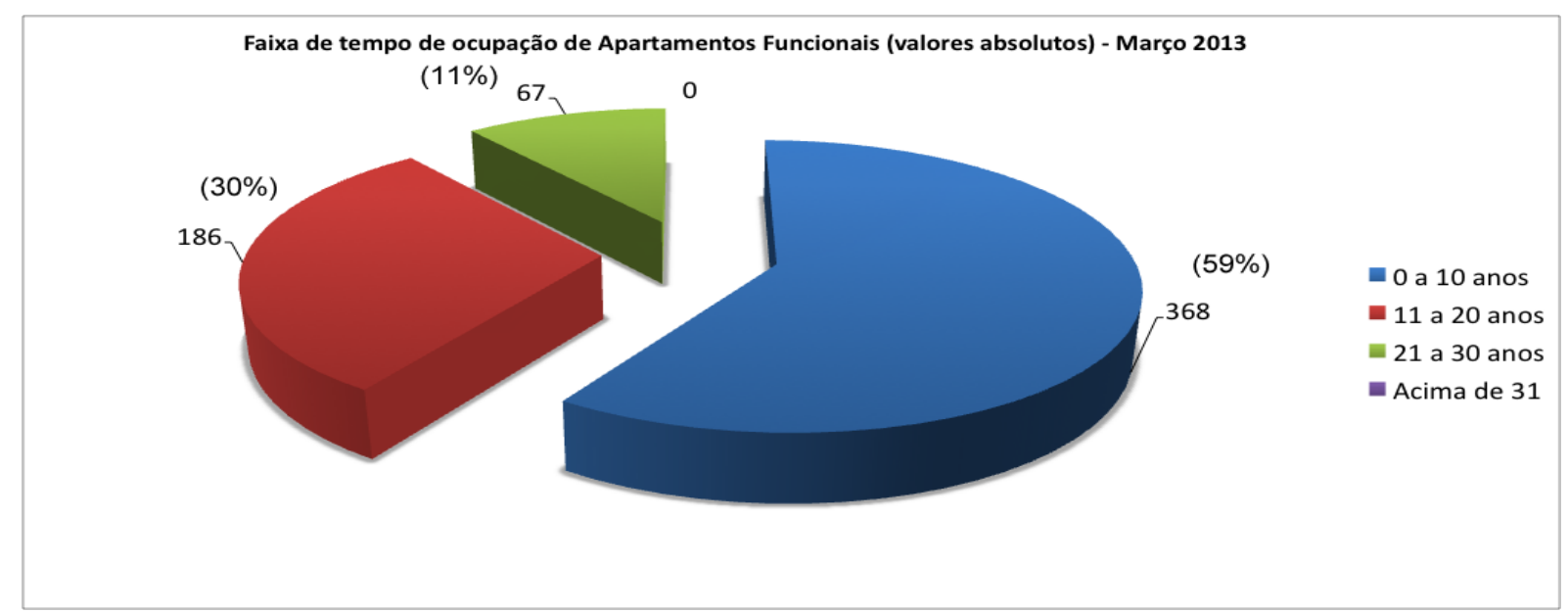

Fonte: Relatório da I Audiência Pública sobre Política de Moradia da Unb,2013. 
O referido documento ratifica os dados levantados neste trabalho, oriundos da análise da carteira imobiliária da FUB/UnB, identificando que, dos 1.514 imóveis residenciais, 679 são destinados à moradia de servidores e os 835 imóveis da instituição estão concentrados da seguinte forma:

- Ocupação por terceiros, público externo à FUB (71\%);

- Servidores da FUB/UnB com desconto de 20\% (29\%).

Tais situações dificultam 0 acesso de novos docentes e técnicos administrativos aos imóveis subsidiados.

Figura 03: Demonstrativo da distribuição dos Imóveis alugados (SGP) agrupados por categorias Terceiros (Público externo à FUB/UnB) e Servidores da FUB/UnB (aluguel com 20\% de desconto)

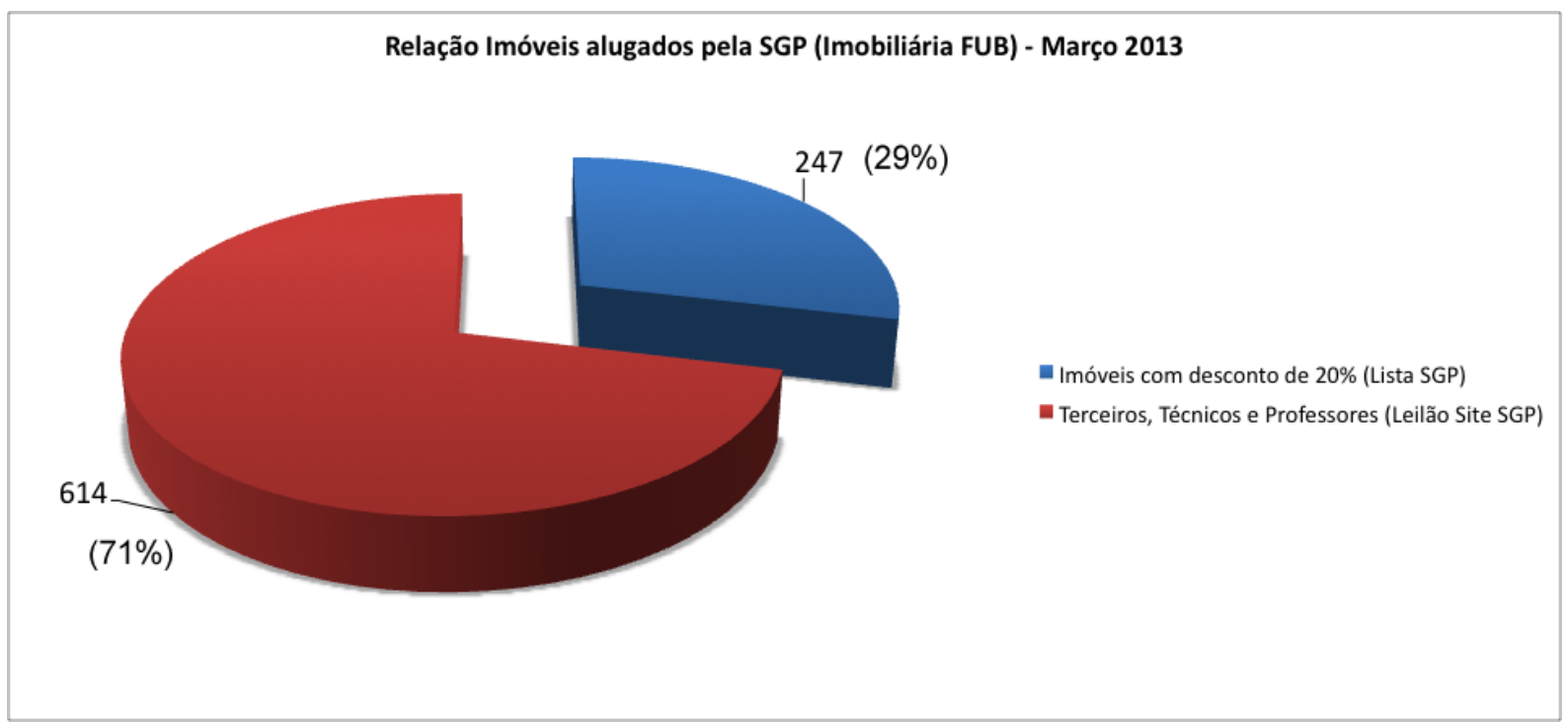

Fonte: Relatório da I Audiência Pública sobre Política de Moradia da Unb,2013.

Conforme o Sistema Integrado de Administração de Recursos Humanos SIAPE, a quantidade de servidores ativos da FUB em 2009 era de 5.504, em 2010 era de 5.412, 2011, de 5.319, 2012, de 5.226 e em 2013 era de 5.122. A quantidade de imóveis destinados exclusivamente aos servidores é de 679. O número de funcionários, portanto, é oito vezes maior que o de imóveis disponíveis, de movo que aproximadamente $13 \%$ de técnicos e docentes são beneficiados. 


\subsection{ESTUDO PARA AMPLIAÇÃO DO BENEFÍCIO}

No intuito de melhorar a situação de um indivíduo, sem piorar a situação dos demais, será verificado se existe outra alocação possível de recurso que gere um valor adicional a ser destinado como subsídio de moradia para os servidores da UnB, observando que o valor desse subsídio não provoque alteração no custo de moradia dos que já recebem o benefício. O intuito é o de que uma população maior seja alcançada com o benefício; para isso, a teoria da melhoria de Pareto será aplicada no estudo.

O ótimo de Pareto é um conceito bastante utilizado pela ciência econômica como critério para avaliar a eficiência. Diz-se que uma situação é eficiente ou ótima de Pareto se não existir nenhuma forma de melhorar a situação de algum agente econômico (empresa ou consumidor) sem piorar a de um outro agente (GEOFFROY, 2010).

Outro conceito de eficiência econômica é o sugerido por KALDOR-HICKS, que se diferencia do critério de PARETO ao admitir a existência de uma mudança social eficiente mesmo quando o aumento do bem-estar de uma parte resulta na redução do bem-estar de outra, desde que a parte cujo bem-estar sofreu redução possa ser compensada para manter o seu nível de satisfação. (LEMOS,1999). Verifica-se que, pelo critério de PARETO, essa troca não seria possível porque resultaria em "perda" para determinado indivíduo, mas pelo critério de KALDORHICKS a troca é viável, pois basta haver a possibilidade de compensação dos "perdedores" pelos "ganhadores", ainda que essa compensação seja teórica. (NIED, 2012)

\subsection{CUSTO DE OPORTUNIDADE}

O estudo do custo de oportunidade aplicado aos imóveis da FUB tem o intuito de comparar com a escolha de uma segunda oportunidade de benefícios ainda não aproveitada. A análise será realizada com base na receita de que a UnB abre mão todo mês por não contabilizar os aluguéis dos imóveis da FUB a preço de mercado. A receita não auferida será quantificada em termos reais em custos que poderia 
financiar.

Segundo Bonacim; Cunha; Gonçalves (2008), o custo de oportunidade é um conceito usado em economia e finanças, com o qual se estabelece que os custos não devem ser vistos de maneira isolada, mas comparados com a escolha de uma segunda oportunidade de benefícios não aproveitada. Com o resultado tomado, a escolha fica entre o benefício gerado escolhido e o benefício que será obtido pela escolha da melhor alternativa. Assim, o custo de oportunidade representa o custo associado a uma determinada escolha em termos da melhor oportunidade perdida. A escassez propicia realizarmos escolhas priorizando determinados bens; assim, haverá um custo de oportunidade sempre que tomarmos uma decisão.

O conceito de custo de oportunidade é sempre presente quando a aceitação de uma alternativa exclui outras. Assim, "representa o custo de oportunidade o quanto a empresa sacrificou em termos de remuneração por ter aplicado seus recursos numa alternativa ao invés de outra" (MARTINS, 1995, p. 208).

A definição de custo de oportunidade é dada por Frederic Von Wieser ao comentar que, à medida que uma decisão de produção é tomada, dada a escassez dos recursos existentes, os recursos inerentes a serem consumidos ficam comprometidos com aquela produção em particular, não podendo ser utilizados para satisfazer uma decisão de produção de outro bem (BURCH e HENRY, 1974, p.118123).

Segundo Pereira; Redaelli; Imonian, (2009) a visão econômica do custo de oportunidade pode ser entendida como um estudo da escassez e dos fenômenos delas resultantes, de forma mais sofisticada, como o estudo da alocação de recursos escassos entre usos alternativos com vistas à satisfação das necessidades.

\subsection{ECONOMIA NORMATIVA E ECONOMIA POSITIVA}

A Economia nasce da necessidade de se estudar como a sociedade utiliza os recursos restritos existentes, na tentativa de alcançar a satisfação e o bem-estar. Sendo os recursos limitados, é preciso fazer escolhas. GREMAUD et al. (2004) explicam que, na teoria econômica, há os argumentos positivos que dizem respeito ao que "é, foi ou será", sendo que a validade do argumento pode ser apropriadamente confrontada com os fatos da realidade. Os argumentos normativos 
dizem respeito ao que "deveria ser", são impregnados de critérios filosóficos, religiosos ou culturais.

De acordo com Mankiw (2009, p. 28), "uma diferença fundamental entre as declarações positivas e as normativas está em como julgamos sua validade. Podemos em princípio confirmar ou refutar as afirmações positivas por meio de exames de evidência".

A capacidade de separar os juízos normativos dos positivos deve ser vista como uma das principais razões do progresso e do êxito da economia enquanto ciência e também de outros ramos do conhecimento humano (LIPSEY, 1986)

Rossetti (1991) ressalta que é logicamente impossível deduzir regras normativas, dadas como definitivas, verdadeiras e irrefutáveis, apenas de afirmações positivas. Porém essa ressalva não implica necessariamente a inexistência de ligações entre a economia positiva e normativa.

Para Friedman (1981, p.163-200):

"Seguindo essa tradição, distingue a ciência positiva (aquilo que é) da ciência normativa (aquilo que deve ser); ele estabelece a diferença entre pressupostos, hipóteses e implicações. Os pressupostos não estão sujeitos a testes empíricos, mas são aceitos como verdades "a priori". Eles são estabelecidos pelo raciocínio 1ógico, formando um corpo teórico, através do qual as hipóteses a serem testadas são deduzidas. Feito o teste, chega-se a verdades universais (indução), generalizando-se as implicações da aceitação ou da rejeição das hipóteses para o universo dos dados."

Conforme ludícibus, Martins e Carvalho (2005), a teoria normativa apoia-se principalmente no método dedutivo e deriva de prescrições de como a contabilidade deveria proceder para maximizar a utilidade da informação para os variados tipos de usuários.

De acordo com Dias Filho e Machado (2004), a teoria positiva "tem por finalidade fornecer subsídios para explicar e predizer determinados fenômenos".

\subsection{EFICIÊNCIA E ECONOMICIDADE}

A Eficiência e a Economicidade são dois princípios importantes para a Administração Pública, no sentido de que inovar a atuação da administração pública de forma eficiente e econômica tornou-se imprescindível na execução administrativa. 
De acordo com Meirelles (2006, p. 96),

"eficiência é o mais moderno princípio da função administrativa, que já não se contenta em ser desempenhada apenas com legalidade, exigindo resultados positivos para o serviço público e satisfatório atendimento das necessidades da comunidade e de seus membros".

Di Pietro diz que

"[...] o princípio da eficiência apresenta, na realidade, dois aspectos: pode ser considerado em relação ao modo de atuação do agente público, do qual se espera o melhor desempenho possível de suas atribuições, para lograr os melhores resultados; e em relação ao modo de organizar, estruturar, disciplinar a Administração Pública, também com o mesmo objetivo de alcançar os melhores resultados na prestação do serviço público." (DI PIETRO, 2005, p. 84)

De acordo com Onofre Batista Júnior, o princípio da economicidade

"Pode ser considerado como um dos vetores fundamentais para a verificação da boa ou eficiente administração. Tal concepção associa-se à ideia fundamental de obter o melhor resultado estratégico possível a partir de determinada alocação de recursos econômico-financeiros, em dado cenário socioeconômico." (BATISTA JÚNIOR., 2004, p.776)

Para CAIDEN; CAIDEN (2001, p. 82) a eficiência é a relação entre os insumos e os resultados, sendo exemplos a utilização do mínimo de insumos para produzir um determinado resultado ou a obtenção de máximos resultados para um determinado nível de insumos.

Silva, (2002, p. 651), explica:

"[...] a eficiência administrativa, como corolário da economicidade, tem uma vertente de maximização do recurso público a ser despendido pela Administração Pública, pelo que, para ser eficiente, a atividade administrativa empreendida deverá trazer benefícios para a coletividade compatíveis com o montante de recursos públicos despendidos."

A conceituação do princípio de economicidade feita por Bugarin (2004, p.129) "é a busca permanente pelos agentes públicos da melhor alocação possível dos escassos recursos públicos para solucionar ou mitigar os problemas sociais existentes".

Assim, os princípios mostram que deve haver um equilíbrio entre a eficiência e a economicidade na Administração Pública, contemplando a redução de custos com execução eficiente dos serviços. 


\section{METODOLOGIA}

Esta pesquisa tem como objetivo avaliar a contribuição econômico-financeira do Sistema Imobiliário da FUB para a Universidade. Para sua realização, na intenção de descrever a dinâmica do assunto estudado, será realizado um estudo de caso e, para isso, escolhida a Fundação Universidade de Brasília.

Apresentam-se neste capítulo o tipo de pesquisa, a caracterização da FUB como lócus da pesquisa, os instrumentos de pesquisa, a descrição dos procedimentos de coleta e de análise de dados utilizados.

Quanto à natureza da pesquisa, o estudo foi exploratório, possibilita uma proximidade sobre o tema e estimula o desenvolvimento de hipóteses, que tornam o problema mais explícito. Essa pesquisa também é descritiva, o estudo detalha e descreve o fenômeno e aponta as formas em que ocorre. O estudo também é experimental quando há interpretações e avaliações na aplicação de determinados fatores ou simplesmente dos resultados já existentes dos fenômenos.

O estudo é relacionado a Finanças Públicas, procura demonstrar a contribuição econômico-financeira do Sistema Imobiliário da FUB para a Universidade, bem como empregar a teoria de Custo de Oportunidade como alternativa não aproveitada.

O período da pesquisa é de 2009 a 2013 e os instrumentos utilizados foram: coletas de dados sobre os imóveis no Sistema Integrado de Administração Financeira do Governo Federal - SIAFI, CONSIAF, programa que extrai informações consolidadas do SIAFI, no Sistema Integrado de Administração de Pessoal - SIAPE, na SGP da Universidade, Decanato de Gestão Pessoas - DGP. Foram feitas consultas também ao portal da Diretoria de Orçamento e Finanças e aos boletins do Sindicato da Habitação do DF - SECOVI - DF.

A FUB distingue-se das demais Instituições Federais de Ensino Superior por possuir terrenos adquiridos com sua criação, possuir uma carteira imobiliária de 1.690 imóveis, 1.514 residenciais e 176 comerciais, 26 vagas de garagem, 26 projeções na Asa Norte e um lote no Setor Hoteleiro Norte.

A primeira etapa da pesquisa iniciou com a coleta de dados sobre os imóveis da FUB, na SGP da instituição, setor que planeja, coordena e supervisiona o processo de gestão patrimonial dos imóveis residenciais e comerciais da instituição. 
Nessa etapa, foram classificados os dados dos imóveis por localização, tipo de apartamento, metragem, valor do aluguel adotado pela FUB em cada exercício, calculada a média do valor de aluguel, quantidade de apartamentos e tipo de apartamento.

$\mathrm{Na}$ segunda etapa, a tarefa foi identificar o instrumento confiável para ser fonte de pesquisa para aplicação dos dados dos imóveis da FUB e evidenciação do valor venal e do valor de alocação a preço de mercado. O SECOVI-DF foi escolhido como instrumento de pesquisa, pois sua representação abrange as empresas de compra e venda de imóveis, as imobiliárias, as administradoras de imóveis e as incorporadoras do Distrito Federal.

$\mathrm{Na}$ terceira etapa, foram utilizados os resultados dos valores de aluguel a preço de mercado e os valores de venda a preço de mercado no estudo do custo de oportunidade aplicado ao sistema imobiliário da FUB. Com isso, objetivou-se estimar a economicidade de uma outra opção ou verificar o custo/benefício, na tentativa de atingir um resultado mais favorável para a instituição e um resultado igualitário para o corpo funcional.

\subsection{DESCRIÇÃO E ANÁLISE DE DADOS}

A UnB se sobressai entre as instituições de ensino superior do país e é considerada, pelo Ranking Universitário da Folha (RUF) 2014, elaborado pelo jornal Folha de São Paulo, a oitava melhor instituição de ensino superior do país, ocupando o $17^{\circ}$ lugar na lista das melhores instituições de ensino superior da América Latina.

O Quadro 1 demonstra, de modo simplificado, as cinco etapas desta pesquisa, os objetivos de cada uma e forma de coleta:

Quadro 01: Etapas, objetivos e instrumentos de pesquisa

\begin{tabular}{|l|l|l|l|}
\hline Etapa & Dados & Objetivo & Coleta \\
\hline \multirow{3}{*}{ PRIMEIRA } & Receita e Despesa da atividade imobiliária & Análise & SIAFI/CONSIAFI \\
\cline { 2 - 4 } & Renúncia de Receita e Inadimplência & Análise & SGP \\
\cline { 2 - 4 } & Orçamento da FUB & Análise & Senado Federal \\
\hline \multirow{2}{*}{ SEGUNDA } & Os endereços & Aluguel adotado & SGP \\
\hline
\end{tabular}


Quadro 01: Etapas, objetivos e instrumentos de pesquisa

\begin{tabular}{|l|l|l|l|}
\hline Etapa & Dados & Objetivo & Coleta \\
\hline \multirow{5}{*}{} & Os tipos de apartamentos & Beneficiados & \\
\cline { 2 - 4 } & A metragem & Vantagens & \\
\cline { 2 - 4 } & Localização & Aluguel de mercado & SEGEJ/flusão) \\
\cline { 2 - 4 } & A quantidade de apartamentos & Diferença de aluguel & \\
\cline { 2 - 4 } & Tipo de aluguel & & \\
\cline { 2 - 4 } & Quantidade de salas cedidas & & \\
\hline \multirow{2}{*}{ TERCEIRA } & Aluguel a preço de mercado & Custo de oportunidade & SECOVI-DF \\
\cline { 2 - 4 } & Valor venal & Identificar Ganhos ou Perdas & Análise \\
\hline QUARTA & Evidenciação dos resultados & Custo de Oportunidade & Análise \\
\hline QUINTA & Aplicação do resultado & &
\end{tabular}

Fonte: SIAFI, SGP, SECOVI, 2015.

Elaborado pela autora

A primeira etapa da pesquisa iniciou com a coleta de dados sobre os imóveis da FUB, na SGP da instituição, setor que planeja, coordena e supervisiona o processo de gestão patrimonial dos imóveis residenciais e comerciais da instituição. Nessa etapa, foram classificados os dados dos imóveis por localização, tipo de apartamento, metragem, valor do aluguel adotado pela FUB em cada exercício, calculada a média do valor de aluguel, quantidade de apartamentos e tipo de apartamento.

$\mathrm{Na}$ segunda etapa, a tarefa foi identificar o instrumento confiável para ser fonte de pesquisa para aplicação dos dados dos imóveis da FUB e evidenciação do valor venal e do valor de alocação a preço de mercado. O SECOVI-DF foi escolhido como instrumento de pesquisa, pois sua representação abrange as empresas de compra e venda de imóveis, as imobiliárias, as administradoras de imóveis e as incorporadoras do Distrito Federal.

Foram classificados os dados dos imóveis da FUB, relativos à localização, metragem do imóvel, número de dormitório e garagem:

1) para estimar o valor de aluguel a preço de mercado, foram utilizados os dados dos Boletins Imobiliários do Secovi/DF, referentes aos preços do metro quadrado para locação e relacionados com as informações dos apartamentos da FUB, como metro quadrado, localização, tipo de apartamento, dos imóveis residenciais e comerciais da FUB, classificados em cada exercício separadamente, de 2009 a 2013;

2) para estimar o valor de venda a preço de mercado, também foram 
utilizados os dados dos Boletins Imobiliários do Secovi/DF, relativos aos preços do metro quadrado para venda e relacionados com as informações dos apartamentos da FUB, como metro quadrado, localização, tipo de apartamento, dos imóveis residenciais e comerciais da FUB, classificados em cada exercício separadamente, de 2009 a 2013;

3) os resultados são apresentados em relação aos valores de aluguel e de venda, a preço de mercado, nos diferentes exercícios, para melhor exposição, análise e comparação.

$\mathrm{Na}$ terceira etapa, foram utilizados os resultados dos valores de aluguel a preço de mercado e os valores de venda a preço de mercado no estudo do custo de oportunidade aplicado ao sistema imobiliário da FUB. Com isso, objetivou-se estimar a economicidade de uma outra opção ou verificar o custo/benefício, na tentativa de atingir um resultado mais favorável para a instituição e um resultado igualitário para o corpo funcional.

Nesse sentido, foram criadas as hipóteses A e B como forma de alternativas de gestão do patrimônio imobiliário: 
Quadro 02: Descrição da Construção das formas alternativas de gestão de patrimônio:
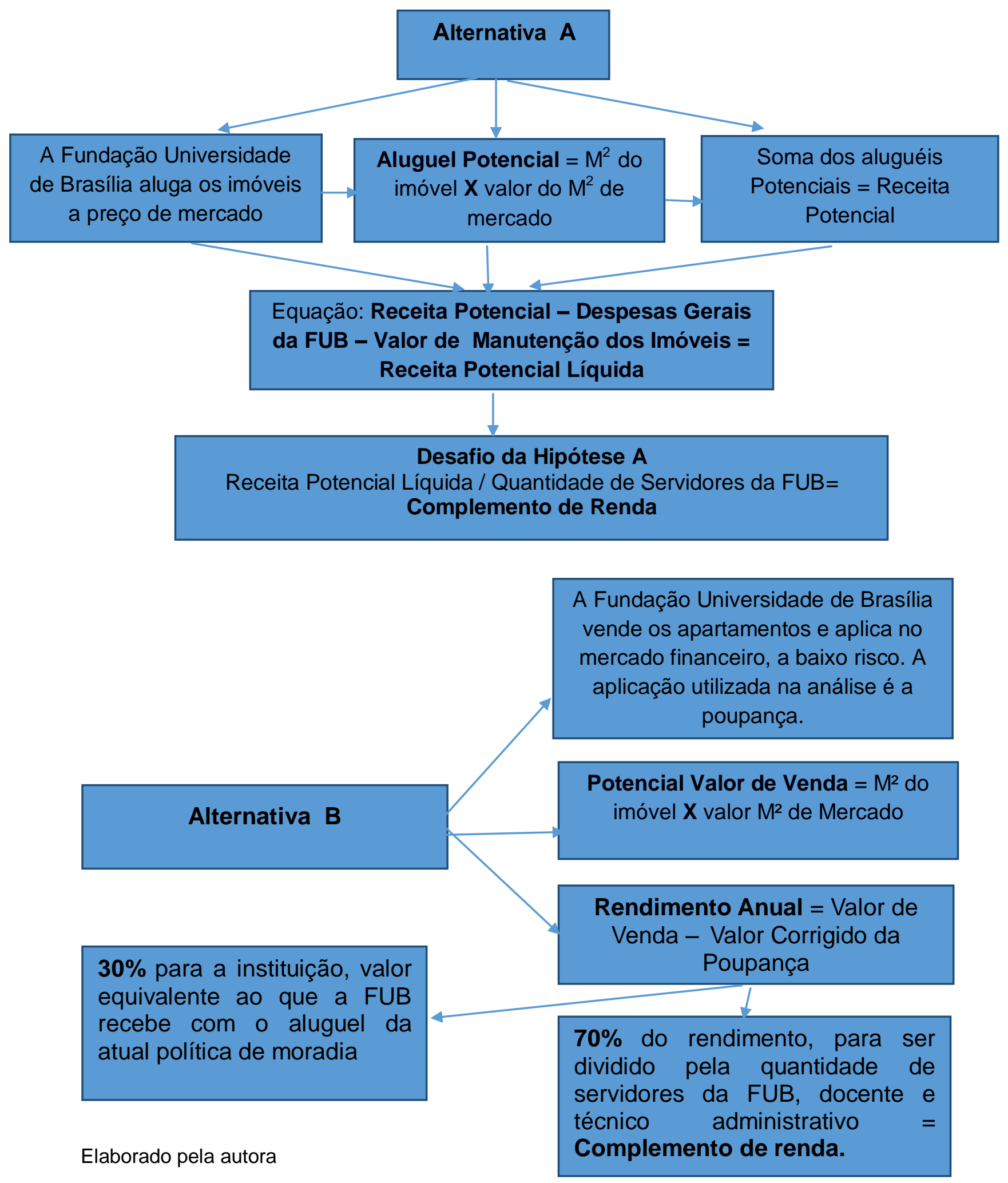

$\mathrm{Na}$ quarta etapa realizou-se a comparação dos dados de aluguel adotado pela FUB com os dados encontrados resultantes da aplicação do valor de mercado, utilizado como fonte a SECOVI-DF. 


\section{RESULTADOS E DISCUSSÃO}

Serão apresentados neste capítulo os resultados da análise documental, de acordo com a ordem dos objetivos específicos, para melhor exposição e análise das evidências.

O desenvolvimento de uma investigação associa-se a uma sequência de momentos ordenados, compreendidos pela definição metodológica e determinados pelos procedimentos de coleta de dados que encaminham a interpretação das informações colhidas à análise (FIORENTINI; LORENZATO, 2006).

\subsection{RECEITAS E DESPESAS RESULTANTES DA ATIVIDADE IMOBILIÁRIA E RENÚNCIA DE RECEITA}

\subsubsection{Receitas e Despesas resultantes da atividade imobiliária}

As receitas e despesas resultantes da atividade imobiliária são valores recebidos pela FUB relativos aos aluguéis de imóveis da FUB, nos exercícios de 2009 a 2013, e as despesas inerentes ao sistema imobiliário.

Ao analisar a tabela 2, verificamos que os valores recebidos, relativos a apartamentos alugados a terceiros e a servidores contemplados com $20 \%$ de desconto, corresponderam a $61,77 \%$. As despesas relacionadas à gestão patrimonial representaram, nos cinco exercícios, uma média de $22,08 \%$ do recebido. A Taxa de Ocupação correspondeu a uma média de $16,53 \%$ do valor recebido nos cinco exercícios.

É importante ressaltar que o valor relativo ao saldo positivo da SGP é utilizado para pagar as despesas gerais da FUB. Observa-se que o valor recebido referente à taxa de ocupação é equivalente ao valor utilizado para manutenção dos imóveis e os valores recebidos de aluguel ultrapassam $50 \%$ do que a FUB recebe. 
Tabela 01: Receita e despesa da atividade imobiliária - valores nominais.

$R \$ 1,00$

\begin{tabular}{|c|c|c|c|c|c|}
\hline RECEITA & 2009 & 2010 & 2011 & 2012 & 2013 \\
\hline Aluguéis & $18.254 .039,33$ & $20.244 .258,08$ & $20.615 .729,87$ & $22.532 .662,70$ & $23.344 .948,22$ \\
\hline $\begin{array}{l}\text { Taxa de Ocupação de } \\
\text { Imóveis }\end{array}$ & $3.736 .003,00$ & $4.363 .458,97$ & $6.476 .986,22$ & $6.711 .766,46$ & $7.198 .757,41$ \\
\hline Taxa de Condomínio & $4.104 .711,47$ & $6.610 .829,06$ & $3.153 .158,93$ & $5.775 .829,76$ & $7.667 .426,39$ \\
\hline $\begin{array}{l}\text { Receita Direta } \\
\text { Arrecadação da FUB }\end{array}$ & $1.605 .965,41$ & $2.995 .648,72$ & $1.947 .329,62$ & $1.833 .039,96$ & $1.617 .543,60$ \\
\hline SOMA & $27.700 .719,21$ & $34.214 .194,83$ & $32.193 .204,64$ & $36.853 .298,88$ & $39.828 .675,62$ \\
\hline \multicolumn{6}{|l|}{ DESPESA } \\
\hline Material de Consumo & $484.930,11$ & $62.646,75$ & $152.380,30$ & $194.258,34$ & $71.257,37$ \\
\hline $\begin{array}{lrr}\text { Outro } & \text { Serviços } & \text { de } \\
\text { Terceiro } & - & \text { Pessoa } \\
\text { Jurídica } & & \\
\end{array}$ & $5.128 .239,85$ & $7.232 .907,38$ & 2.767.029,90 & $2.789 .102,72$ & $3.569 .279,79$ \\
\hline $\begin{array}{llr}\text { Outro } & \text { Serviços } & \text { e } \\
\text { Terceiro } & - & \text { Pessoa } \\
\text { Física } & & \\
\end{array}$ & $24.300,00$ & $106.682,34$ & $129.380,42$ & & \\
\hline $\begin{array}{l}\text { Obrigações tributárias e } \\
\text { contributivas }\end{array}$ & $40.772,10$ & $112.051,47$ & $58.959,21$ & $30.220,41$ & \\
\hline $\begin{array}{l}\text { Obrigação tributária e } \\
\text { contributivas-Operação } \\
\text { Intra-Orçamentária. }\end{array}$ & $4.910,00$ & $21.336,48$ & $25.876,08$ & & \\
\hline $\begin{array}{l}\text { Equipamento e Material } \\
\text { Permanente }\end{array}$ & $23.620,82$ & $45.232,34$ & $6.450,00$ & $15.127,00$ & $58.145,00$ \\
\hline Obras e Instalações & & $2.025 .621,02$ & $299.745,99$ & $151.102,61$ & \\
\hline $\begin{array}{l}\text { Locação de Mão de } \\
\text { Obra }\end{array}$ & & & $1.660 .666,65$ & $4.429 .058,64$ & $6.366 .446,66$ \\
\hline $\begin{array}{l}\text { Despesa do Exercício } \\
\text { Anterior }\end{array}$ & $3.904,00$ & & & & 973,45 \\
\hline SOMA & $5.710 .676,88$ & $9.606 .477,78$ & $5.100 .488,55$ & $7.608 .869,72$ & $10.066 .102,27$ \\
\hline $\begin{array}{ll}\text { SALDO } & \text { POSITIVO } \\
\text { SGP } & \\
\end{array}$ & $21.990 .042,33$ & $24.607 .717,05$ & 27.092.716,09 & $29.244 .429,16$ & $29.762 .573,35$ \\
\hline TOTAL & $27.700 .719,21$ & $34.214 .194,83$ & $32.193 .204,64$ & $36.853 .298,88$ & $39.828 .675,62$ \\
\hline
\end{tabular}

Fonte: SIAFI/ CONSIAFI, 2015.

Elaborado pela autora

Verifica-se também que, no exercício de 2010, o valor da despesa foi alavancado pela conta de Obras e Instalações, no valor de $R \$ 2.025 .621,02$. A despesa de Outros Serviços de Terceiro de Pessoa Jurídica, se apresentou no valor de $R \$ 7.232 .907,38$, tendo em vista a despesa orçamentária ter sido empenhada, mas não paga até o dia 31 de dezembro, final do exercício financeiro, assim foi considerada como Restos a Pagar, para fins de encerramento do correspondente exercício financeiro. Uma vez empenhada, a despesa pertence ao exercício financeiro em que o empenho ocorreu, onerando a dotação orçamentária do exercício de 2010.

Os exercícios de 2012 e 2013 destacam-se pelo aumento da despesa com Locação de Mão de Obra, com valores de $R$ \$ 4.429.058,64 em 2012 e $R$ \$ 
6.366.446,66 em 2013, o que representou um aumento de 143,74\% de um exercício para o outro, ocasionado pela contratação de empresas terceirizadas.

O valor relativo ao Saldo Positivo da SGP é utilizado para pagar as despesas gerais da Universidade de Brasília, correspondentes a 77,9\% dos valores recebidos pela FUB, resultantes dos contratos de aluguel residencial, comercial e de taxa de ocupação.

\subsubsection{Despesa com manutenção e reforma dos imóveis - 2009 a 2013}

Ao analisar a receita advinda dos imóveis em relação a despesas com Manutenção e Reforma de Infraestrutura, verifica-se que a despesa não é tão expressiva.

Tabela 02: Despesa com manutenção e reformas - valores nominais

$R \$ 1,00$

\begin{tabular}{|l|r|r|r|r|r|}
\hline \multicolumn{6}{|c|}{ Material para Manutenção e Reformas de Infraestrutura dos Imóveis da FUB } \\
\hline & \multicolumn{1}{|c|}{2009} & \multicolumn{1}{c|}{2010} & \multicolumn{1}{c|}{2011} & 2012 & 2013 \\
\hline $\begin{array}{l}\text { Material para } \\
\text { Manutenção de } \\
\text { Imóveis/Instalações. }\end{array}$ & $426.254,04$ & $42.684,82$ & $137.673,05$ & $179.864,71$ & $36.624,86$ \\
\hline $\begin{array}{l}\text { Manutenção e } \\
\text { Conservação de } \\
\text { Bens Imóveis }\end{array}$ & $107.833,86$ & $97.568,65$ & $156.110,50$ & $287.250,67$ & $701.331,67$ \\
\hline Estudos e Projetos & & $189.734,33$ & & & \\
\hline $\begin{array}{l}\text { Obras em } \\
\text { andamento }\end{array}$ & & $103.847,58$ & $299.745,99$ & $151.102,61$ & \\
\hline Instalações & $1.724 .073,11$ & & & \\
\hline $\begin{array}{l}\text { Outras obras e } \\
\text { instalações }\end{array}$ & $7.966,00$ & & & \\
\hline Seguro em geral & & & $19.050,00$ & & \\
\hline Total & $534.087,90$ & $2.165 .874,49$ & $612.579,54$ & $618.217,99$ & $737.956,53$ \\
\hline
\end{tabular}

Fonte: SIAFI/CONSIAFI, 2015.

Elaborado pela autora

A Despesa com Manutenção e Reforma representa, em média, 4\% da receita resultante dos aluguéis dos imóveis da FUB, que foi reforçada pelo exercício de 2010, quando houve um crescimento no valor da despesa, em decorrência das obras realizadas no exercício. 
Figura 04: Despesa com manutenção e reforma em relação à receita realizada - valores nominais/porcentagem

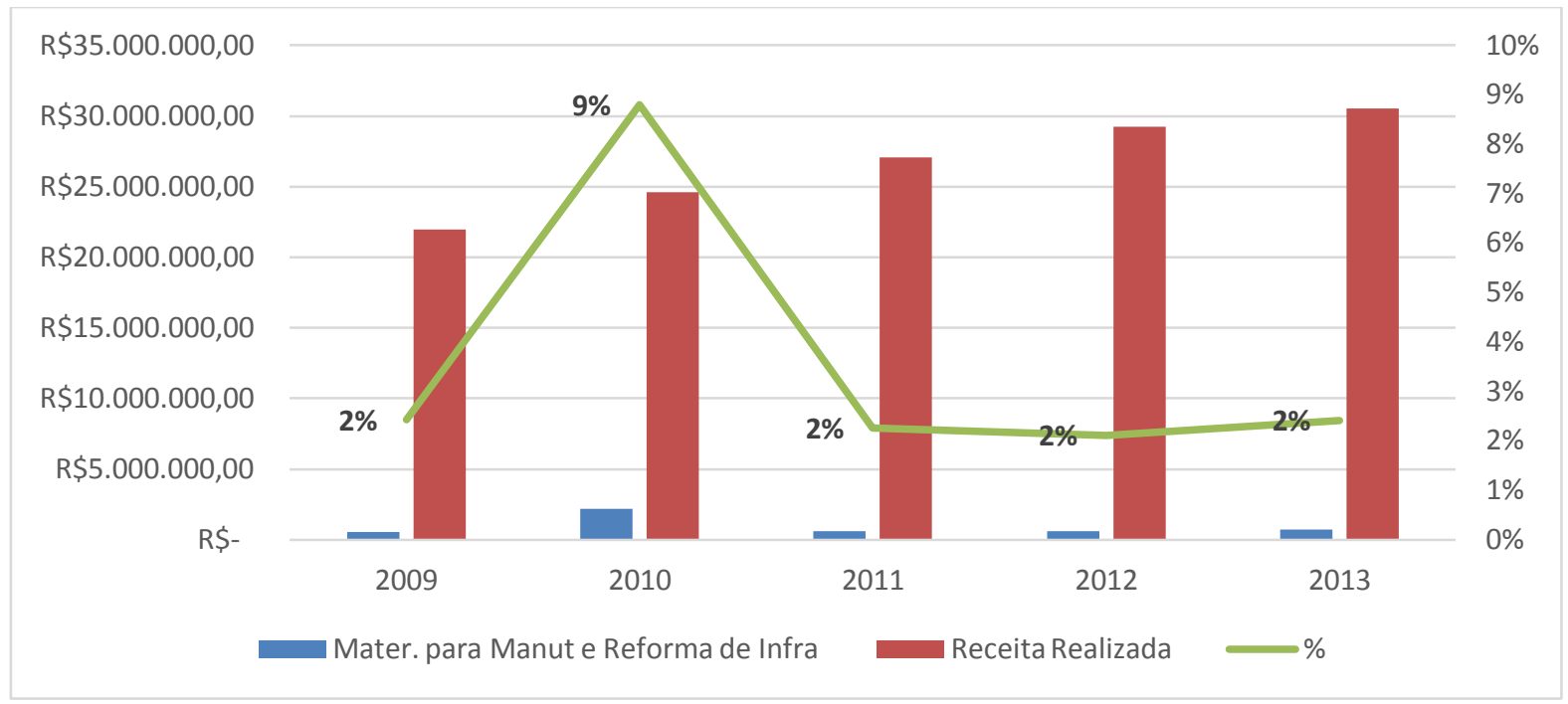

Fonte: SIAFI/CONSIAFI, 2015

Elaborada pela autora

\subsubsection{Despesa com pessoal, limpeza, material de consumo e serviços}

Observa-se que é nesse grupo de despesas que se concentra um maior aporte da receita realizada para manter as necessidades de manutenção de toda natureza aos imóveis.

Tabela 03: Despesa para manutenção dos imóveis - valores nominais

\begin{tabular}{|l|r|r|r|r|r|}
\hline \multicolumn{1}{|l|}{2009} & \multicolumn{1}{c|}{$R \$ 1,00$} \\
\hline Material de consumo & $58.676,07$ & $19.961,93$ & $14.707,25$ & $14.393,63$ & $34.632,51$ \\
\hline $\begin{array}{l}\text { Outros serviços de rerceiro } \\
\text { pessoa física }\end{array}$ & $24.300,00$ & $106.682,34$ & $129.380,42$ & & \\
\hline $\begin{array}{l}\text { Outros serviços de terceiro } \\
\text { pessoa jurídica }\end{array}$ & $4.999 .640,46$ & $7.124 .194,32$ & $2.589 .244,40$ & $2.501 .582,05$ & $2.867 .198,12$ \\
\hline $\begin{array}{l}\text { Obrigações tributárias e } \\
\text { contributivas }\end{array}$ & $40.772,10$ & $66.330,55$ & & & \\
\hline Despesa do exercício anterior & $3.904,00$ & & & & 973,45 \\
\hline $\begin{array}{l}\text { Obrigação tributária e } \\
\text { contributiva - operação intra- } \\
\text { orçamentária }\end{array}$ & $4.910,00$ & $21.336,48$ & $25.876,08$ & & \\
\hline $\begin{array}{l}\text { Equipamento e material } \\
\text { permanente }\end{array}$ & $23.620,82$ & $45.232,34$ & $6.450,00$ & $15.127,00$ & $58.145,00$ \\
\hline $\begin{array}{l}\text { Contribuição previdenciária- } \\
\text { serviços de terceiros }\end{array}$ & & $45.720,92$ & $58.929,21$ & $30.220,41$ & \\
\hline Locação de mão de obra & & & $1.660 .666,65$ & $4.429 .058,64$ & $6.366 .446,66$ \\
\hline Total & $5.155 .823,45$ & $7.429 .458,88$ & $4.485 .284,01$ & $6.990 .381,73$ & $9.327 .395,74$ \\
\hline
\end{tabular}

Fonte: SIAFI/CONSIAFI, 2015.

Elaborado pela autora 
Ao analisar a representatividade das despesas com limpeza, zeladoria, elevadores, pessoal, material de consumo, serviços, verifica-se que a média do impacto dessas despesas na receita resultante dos aluguéis dos imóveis é significante, 24\%, considerando que são despesas relevantes para manter os imóveis em condições de uso.

Figura 05: Representatividade da despesa com pessoal, serviços e material - Valores Nominais/Porcentagem

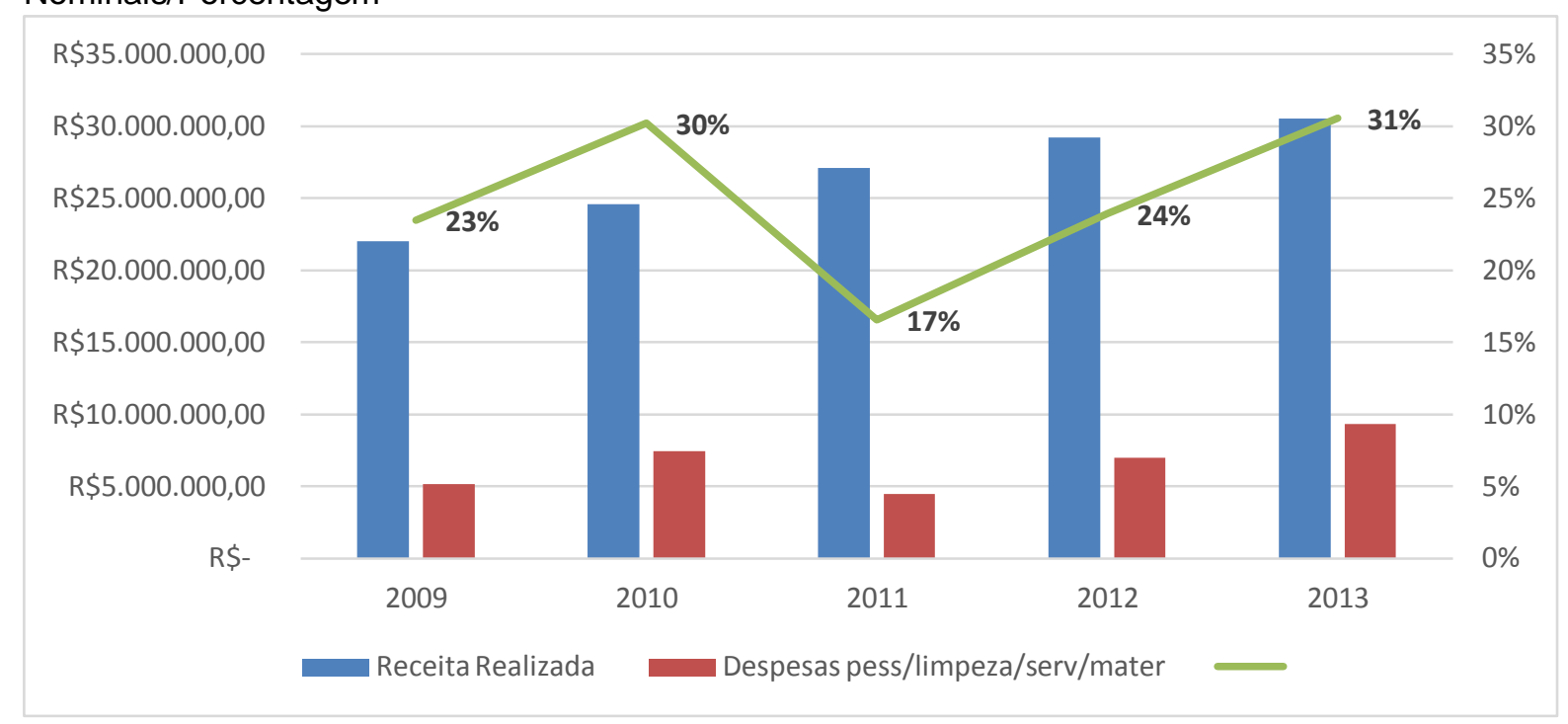

Fonte: SIAFI/CONSIAF,2015.

Elaborada pela autora

É possível verificar que os custos, classificados como despesas operacionais inerentes às atividades imobiliárias, no período de 2009 a 2013, representam em média $28 \%$ da receita provinda dos aluguéis dos imóveis. A inadimplência equivale a menos de $1 \%$ da receita, os custos com reforma de infraestrutura representam em média 4\%, e a despesa com contratação de pessoal, limpeza, serviços em geral e ferramentas absorvem a maior parcela dos gastos com a manutenção dos imóveis.

Verificou-se ainda que o custo com pessoal, limpeza e serviços tem um aumento crescente no período e corresponde em média a $86 \%$ da despesa total relacionada ao sistema imobiliário.

Tabela 04: Detalhamento das despesas para manutenção e conservação dos imóveis - Valores Nominais 


\begin{tabular}{|l|r|r|r|r|r|}
\hline & $\begin{array}{c}\text { Receita } \\
\text { Realizada }\end{array}$ & Inadimplência & $\begin{array}{c}\text { Despesa com } \\
\text { Manutenção } \\
\text { Reforma }\end{array}$ & $\begin{array}{c}\text { Despesa com Limpeza, } \\
\text { Pessoal, Serviço e } \\
\text { Material }\end{array}$ & $\begin{array}{c}\text { R(conclusão) } \\
\text { Receital } \\
\text { Líquida }\end{array}$ \\
\hline 2009 & $21.990 .042,33$ & $43.165,79$ & $554.853,43$ & $5.155 .823,45$ & $16.236 .199,66$ \\
\hline 2010 & $24.607 .727,05$ & $40.706,04$ & $2.177 .018,90$ & $7.429 .458,88$ & $14.960 .543,23$ \\
\hline 2011 & $27.092 .716,09$ & $23.779,73$ & $615.204,54$ & $2.824 .587,36$ & $23.629 .144,46$ \\
\hline 2012 & $29.244 .429,16$ & $132.475,37$ & $618.487,99$ & $6.990 .381,73$ & $21.503 .084,07$ \\
\hline 2013 & $30.543 .705,63$ & $199.804,63$ & $738.706,53$ & $9.327 .395,74$ & $20.277 .798,73$ \\
\hline
\end{tabular}

Fonte: SIAFI/CONSIAFI/SGP,2015.

Elaborado pela autora

Tendo em vista os aspectos analisados, observa-se que a Receita Líquida, aproximadamente $70 \%$ da receita resultantes dos imóveis, é contabilmente registrada como Recurso Próprio e utilizada para pagamento das variadas despesas da Universidade.

Figura 06: Representatividade da despesa total em relação à receita realizada - Valores Nominais/Porcentagem

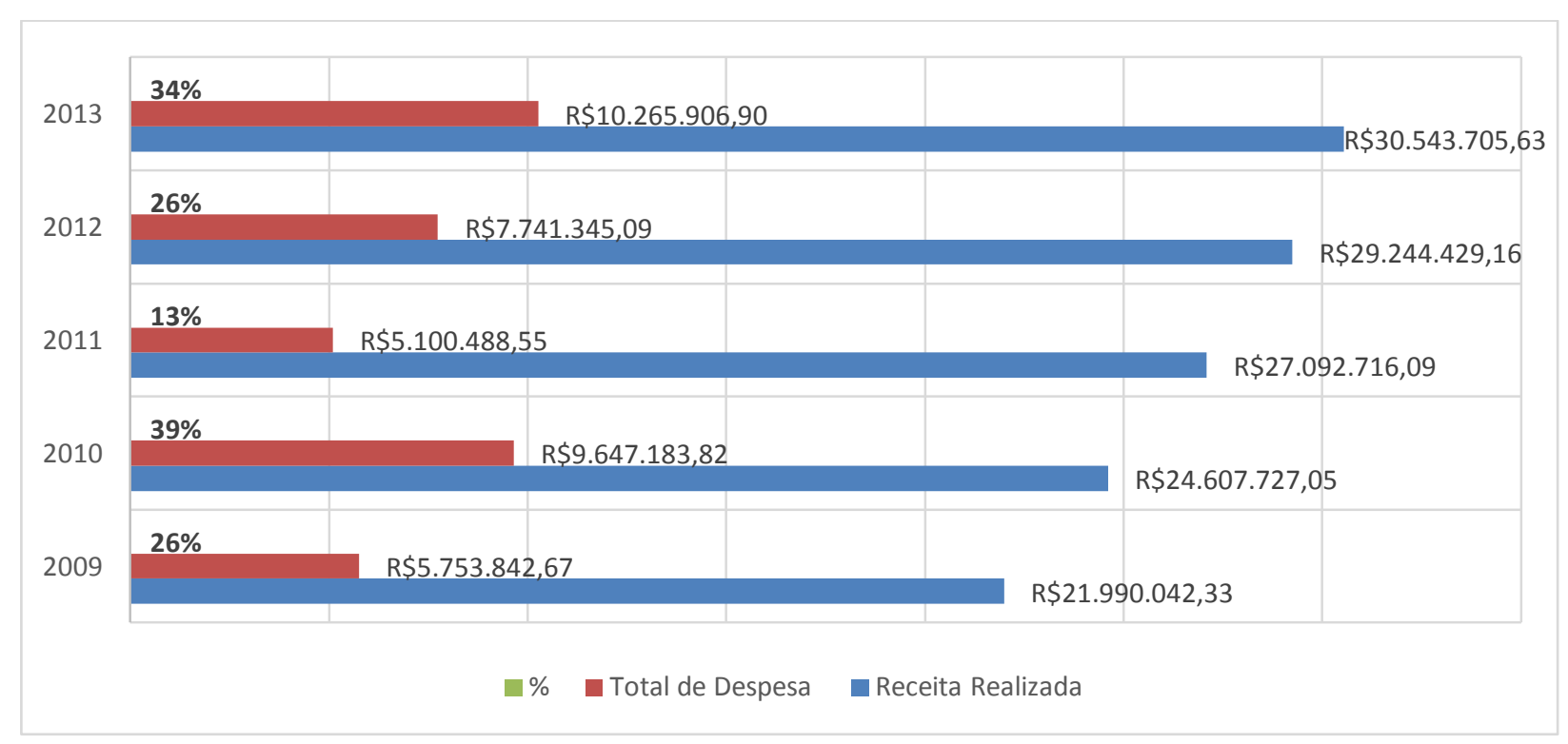

Fonte: SIAFI/CONSIAFI, 2015.

Elaborada pela autora

\subsubsection{Renúncia de receita}

Conforme a Lei de Responsabilidade Fiscal - LRF, Lei Complementar 101/2000, em seu art. 14, § 1ํa a renúncia de receitas "compreende anistia, remissão, subsídio, crédito presumido, concessão de isenção em caráter geral, 
alteração de alíquota ou modificação de base de cálculo que implique redução discriminada de tributos ou contribuições, e outros benefícios que correspondem a tratamento diferenciado".

Em fevereiro de 2013, por meio da Resolução da Reitoria ํo 0031/2013, foi criada uma comissão com o objetivo de planejar, executar e avaliar a Audiência Pública sobre Políticas de Moradia da FUB. A comissão identificou que, durante dezessete anos, de 1998 a 2013, os valores referentes às taxas de ocupação não sofreram reajustes. Nesse período, eram estes os valores:

Tabela 05: Taxa de ocupação sem reajuste - valores nominais:

$\mathrm{R} \$ 1,00$

\begin{tabular}{|l|c|c|}
\hline \multicolumn{1}{|c|}{ Endereço } & Quantidade de Quartos & Valor da Taxa de Ocupação \\
\hline SQN 205 & 3 quartos & 419,00 \\
\hline SQN 206 & 3 quartos & 352,00 \\
\hline Colina Antiga & 2 quartos com DCE & 250,00 \\
\hline Colina Antiga & 2 quartos sem DCE & 193,00 \\
\hline Colina Antiga & 3 quartos & 328,00 \\
\hline Colina Nova & 2 quartos & 303,00 \\
\hline Colina Nova & 3 quartos & 387,00 \\
\hline Colina Nova & 4 quartos & 526,00 \\
\hline
\end{tabular}

Fonte: SGP, 2015

A renúncia de receita adotada pela Universidade constitui-se em uma transferência de renda dos contribuintes brasileiros, que financiam a Universidade por meio de impostos, aos servidores contemplados com o benefício do aluguel subsidiado.

Para demonstrar o impacto financeiro da renúncia de receita no período de 2005 a 2013, fez-se uma comparação ao adotar os valores de aluguel da Colina, SQN 205 e SQN 206, sugeridos nos laudos de avaliação dos imóveis da FUB, elaborados pela Câmara de Valores Imobiliários do Distrito Federal - CVI, empresa escolhida por meio de licitação, com os valores inalterados, adotados pela instituição.

Tabela 06: Receita do termo de ocupação sem atualização dos valores - Valores Nominais 


\begin{tabular}{|c|c|c|c|c|}
\hline \multicolumn{5}{|c|}{ Receita dos imóveis da Colina, SQN 205 e SQN 206, sem atualização } \\
\hline Ano & 2 quartos & 3 quartos & 4 quartos & Total \\
\hline 2009 & $287.928,00$ & $2.350 .512,00$ & $340.848,00$ & $2.979 .288,00$ \\
\hline 2010 & $287.928,00$ & $2.350 .512,00$ & $340.848,00$ & $2.979 .288,00$ \\
\hline 2011 & $287.928,00$ & $2.350 .512,00$ & $340.848,00$ & $2.979 .288,00$ \\
\hline 2012 & $287.928,00$ & $2.350 .512,00$ & $340.848,00$ & $2.979 .288,00$ \\
\hline 2013 & $287.928,00$ & $2.350 .512,00$ & $340.848,00$ & $2.979 .288,00$ \\
\hline
\end{tabular}

Fonte: SGP, 2015.

Elaborado pela autora

Tabela 07: Receita do termo de ocupação corrigido pelo IGP-M (FGV) de 2005 a 2013 - Valores Corrigidos a 2015

$\mathrm{R} \$ 1,00$

\begin{tabular}{|c|r|r|r|r|}
\hline \multicolumn{5}{|c|}{ Receita dos imóveis da Colina, SQN 205 e SQN 206, com atualização } \\
\hline Ano & 2 quartos & \multicolumn{1}{c|}{ 3 quartos } & \multicolumn{1}{c|}{ T quartos } & \multicolumn{1}{c|}{ Total } \\
\hline 2009 & $282.997,92$ & $2.310 .258,24$ & $335.009,52$ & $2.928 .265,68$ \\
\hline 2010 & $320.528,88$ & $2.611 .470,00$ & $379.436,4$ & $3.311 .435,28$ \\
\hline 2011 & $302.608,08$ & $2.470 .330,08$ & $358.220,88$ & $3.131 .159,04$ \\
\hline 2012 & $310.421,52$ & $2.552 .755,68$ & $367.474,32$ & $3.230 .651,52$ \\
\hline 2013 & $303.834,24$ & $2.480 .378,40$ & $366.339,60$ & $3.150 .552,24$ \\
\hline
\end{tabular}

Fonte: SGP e Calculadora do Cidadão do Banco Central, 2015.

Elaborado pela autora

Tabela 08: Total da renúncia de receita - Comparação de Valores Corrigidos e Não Corrigidos.

$\mathrm{R} \$ 1,00$

\begin{tabular}{|c|r|r|r|}
\hline Ano & Receita com atualização & Receita sem atualização & \multicolumn{1}{c|}{ Renúncia de Receita } \\
\hline 2009 & $2.928 .265,68$ & $2.979 .288,00$ & 0,00 \\
\hline 2010 & $3.311,435,28$ & $2.979 .288,00$ & $332.147,28$ \\
\hline 2011 & $3.131 .159,04$ & $2.979 .288,00$ & $151.871,04$ \\
\hline 2012 & $3.230 .651,52$ & $2.979 .288,00$ & $251.363,52$ \\
\hline 2013 & $3.150 .552,24$ & $2.979 .288,00$ & $171.264,24$ \\
\hline \multicolumn{2}{|r|}{ Total da Renúncia de Receita durante os cincos anos } \\
\hline
\end{tabular}

Fonte: SGP, 2015.

Elaborado pela autora

Observa-se nitidamente o valor que a instituição deixou de receber no período avaliado de cinco anos, ressaltando-se que o período sem reajuste foi de dezessete anos. A situação da FUB, que administra recurso escasso com tantas demandas, não coaduna com esse tipo de ação.

Em 30/6/2014, foi assinada a Resolução do Conselho Diretor da FUB 3/2014, que aprovou a tabela básica da Taxa de Ocupação dos imóveis de propriedade da 
FUB, ocupados por seus servidores. A resolução definiu os percentuais a serem aplicados com base nos valores fixados pela Câmara de Valores Imobiliários do Distrito Federal - CVI: $50 \%$ sobre o valor definido pela CVI para renovação dos atuais Termos de Ocupação, com vencimento a partir de 1ำ de julho de 2014; 80\% sobre o valor definido pela CVI para os novos ocupantes.

Os imóveis residenciais ocupados seguem a seguinte divisão:

Tabela 09: Divisão da ocupação dos imóveis residenciais

\begin{tabular}{|l|r|}
\hline Imóveis Residenciais - Termo de Ocupação - ocupados por docentes & 425 \\
\hline Imóveis Residenciais - Termo de Ocupação - ocupados por técnicos administrativos & 202 \\
\hline Total de Termo de Ocupação & 627 \\
\hline Imóveis Residenciais - Lei do Inquilinato - Ocupados por docentes & 30 \\
\hline Imóveis Residenciais - Lei do Inquilinato - Ocupados por técnicos administrativos & 20 \\
\hline Total de aluguel regido pela Lei do inquilinato -docentes e técnicos administrativos & 677 \\
\hline TOTAL & 60 \\
\hline
\end{tabular}

Fonte: Relatório da I Audiência Pública sobre Política de Moradia da UnB, 9/4/2013.

Conforme dados da SGP, as salas e lojas comerciais são destinadas para 0 aluguel comercial e para cessão a órgãos da FUB. Dos 176 imóveis comerciais, aproximadamente 71 são cedidos a esses órgãos. Há também os contratos de Permissão de Uso dos espaços localizados dentro do Campus Darcy Ribeiro.

Considera-se um tipo de renúncia de receita praticada pela FUB, os imóveis comerciais cedidos sem ônus, ressaltando-se que a instituição arca com as despesas de água, luz, condomínio e avarias deixadas por esses órgãos. Informações oficiais por meio de formalização de denúncia não existem, mas é sabido que muitos desses imóveis cedidos são subutilizados ou abandonados.

Segundo informações da SGP, os valores das taxas dos 65 contratos de Permissão de Uso, adotados pela FUB até hoje, foram atualizados em 1998. Esses espaços localizados no campus Darcy Ribeiro receberam nova avaliação de mercado em 2014, mas os novos valores ainda não estão sendo aplicados. Observa-se que as informações da SGP não são precisas por falta de uma automatização confiável. O sistema utilizado pela Secretaria é o mesmo criado em 1998.

Outra situação considerada renúncia de receita é a utilização do Bloco K, localizado na Colina, composto por 18 apartamentos mobiliados e divididos em 72 
ocupações. O bloco é ocupado por alunos de pós-graduação de baixa renda. Cada aluno paga $R \$ 42,00$ de taxa de ocupação. Quando ocorre a ocupação completa dos apartamentos, há uma receita de $\mathrm{R} \$ 3.024,00$.

Outro tipo de renúncia de receita é a resultante da Resolução do Conselho Diretor no 4/1998, que autoriza o Gabinete do Reitor da UnB a utilizar uma cota de 20 apartamentos residenciais de propriedade da FUB, a título de reserva técnica. São imóveis destinados a atrair para os quadros funcionais da Fundação pessoal de alto nível de qualificação, bem como colaboradores diretos da Administração Superior da Universidade, a critério do Reitor.

Por outro lado, é importante ressaltar que os imóveis da FUB são isentos do Imposto sobre a Propriedade Predial e Territorial Urbana - IPTU e da Taxa de Limpeza Pública - TLP, conforme o Ato Declaratório 94/2004 da Subsecretaria da Receita Federal do Governo do Distrito Federal. A renúncia fiscal do GDF foi estimada em 2004 pela sua Subsecretaria em $R$ \$493.350,00.

O valor corrigido pelo INPC - Brasil (FGV) até 2014 fica em $R \$ 861.023,24$. Portanto, a FUB absorve uma receita adicional de uma despesa de impostos sem desembolso de recurso devido à concessão de imunidade e isenção.

\subsection{REPRESENTAÇÃO DA INADIMPLÊNCIA DOS ALUGUÉIS DOS IMÓVEIS DA FUB}

A Tabela 10 mostra o grau de inadimplência dos diferentes contratos imobiliários que a Fundação Universidade de Brasília firma. As informações são extraídas dos relatórios da SGP, referentes aos cinco exercícios.

Tabela 10: Inadimplência dos imóveis da FUB - valores nominais

$\mathrm{R} \$ 1,00$

\begin{tabular}{|l|r|r|r|r|r|}
\hline & \multicolumn{1}{|c|}{2009} & \multicolumn{1}{|c|}{2010} & \multicolumn{1}{c|}{2011} & \multicolumn{1}{c|}{2012} & \multicolumn{1}{c|}{2013} \\
\hline Aluguel Residencial & $35.220,62$ & $35.288,29$ & $13.527,26$ & $21.128,38$ & $137.033,90$ \\
\hline Aluguel Comercial & $2.515,04$ & $2.675,00$ & $2.557,28$ & $9.200,36$ & $8.956,74$ \\
\hline Taxa de Ocupação & $3.104,53$ & $2.742,75$ & $4.426,19$ & $2.146,63$ & 701,04 \\
\hline Taxa de Permissão & $2.325,60$ & & $3.269,00$ & & $53.112,95$ \\
\hline & $43.165,79$ & $40.706,04$ & $23.779,73$ & $132.475,37$ & $199.804,63$ \\
\hline
\end{tabular}


Fonte: Secretaria de Gestão Patrimonial - SGP/FUB, 2014.

O valor da inadimplência em contratos de Aluguel Residencial do exercício de 2012 sobressaiu-se, saltou de $R$ \$ 13.527,26 em 2011 para $R \$ 121.128,38$ em 2012, correspondendo a um aumento de 895,44\%. Observa-se ainda que em 2013 a inadimplência no contrato de Aluguel Residencial foi elevada em 113,13\%, em comparação a 2012. Esses dados sinalizam uma relação com o período de reajuste no valor do aluguel. Segundo informações da SGP, a dívida de aluguel residencial no exercício de 2013, é referente a uma dívida de terceiro extra - FUB.

Observa-se que, com relação à receita dos imóveis da FUB, a inadimplência do contrato de aluguel residencial não é expressiva, a despesa com inadimplência representa menos de $1 \%$ da receita proveniente dos imóveis.

A Coordenação de Cobrança da SGP, responsável por gerenciar as dívidas com aluguéis, taxa de ocupação, taxa de permissão, condomínios e garagem, identifica os casos de inadimplência e solicita a presença dos ocupantes para acordo de pagamento. No entanto, aqueles processos em que a SGP não obtém retorno dos moradores são encaminhados à Procuradoria Jurídica (PJU) para que sejam cobrados judicialmente.

\subsection{ORÇAMENTO DA FUB - 2009 A 2013}

Apresentam-se também as dotações orçamentárias da FUB no período de 2009 a 2013, que servirão para comparar a representatividade da despesa total e da receita realizada resultante dos imóveis.

Tabela 11: Execução orçamentária da FUB - valores nominais

$R \$ 1,00$

\begin{tabular}{|l|l|c|c|c|c|c|}
\hline Ano & $\begin{array}{c}\text { Unidade } \\
\text { Orçamentária }\end{array}$ & $\begin{array}{c}\text { Dotação } \\
\text { Inicial }\end{array}$ & Autorizado & Empenhado & Liquidado & \multicolumn{1}{|c|}{ Pago } \\
\hline 2009 & $26271-$ FUB & 776.526 .231 & 1.055 .779 .047 & 1.001 .119 .979 & 1.001 .119 .979 & 871.756 .157 \\
\hline 2010 & 26271 - FUB & 978.455 .409 & 1.214 .208 .679 & 1.158 .199 .275 & 1.158 .199 .275 & 1.049 .676 .074 \\
\hline
\end{tabular}




\begin{tabular}{|l|l|c|c|c|c|c|}
\hline Ano & $\begin{array}{c}\text { Unidade } \\
\text { Orçamentária }\end{array}$ & $\begin{array}{c}\text { Dotação } \\
\text { Inicial }\end{array}$ & Autorizado & Empenhado & Liquidado & Pago \\
\hline 2011 & 26271 - FUB & 1.180 .911 .399 & 1.333 .157 .748 & 1.237 .377 .078 & 1.237 .377 .078 & 1.141 .825 .243 \\
\hline 2012 & 26271 - FUB & 1.300 .795 .466 & 1.520 .174 .083 & 1.318 .977 .647 & 1.259 .203 .310 & 1.257 .153 .344 \\
\hline 2013 & 26271 - FUB & 1.294 .373 .010 & 1.828 .498 .725 & 1.685 .383 .780 & 1.560 .668 .827 & 1.549 .102 .923 \\
\hline
\end{tabular}

Fonte: Siga Brasil - Senado Federal, 8/5/2015.

No período de 2009 a 2013, a despesa com as atividades imobiliárias representou $1 \%$ das dotações iniciais dos orçamentos anuais da FUB, conforme dados do Siga Brasil - Senado Federal.

Figura 07: Representatividade das despesas de atividades imobiliárias no orçamento da FUB valores nominais.

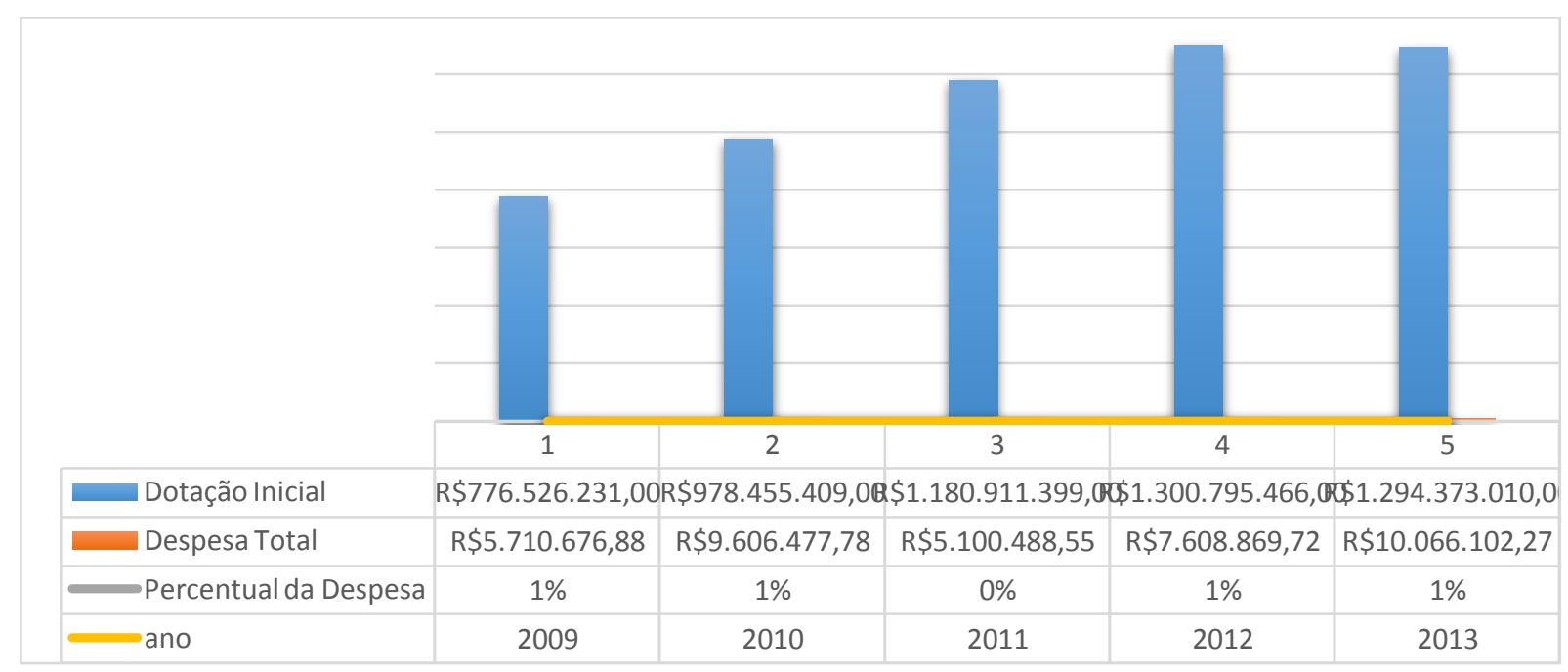

Fonte: Siga Brasil-Senado Federal e SIAFI, 2015.

Elaborada pela autora

Em face dos dados expostos na Figura 4, a representatividade da Receita Realizada proveniente dos imóveis em relação ao Orçamento da FUB é estimada em $2 \%$.

Figura 08: Receita realizada em relação ao orçamento da FUB - valores nominais 


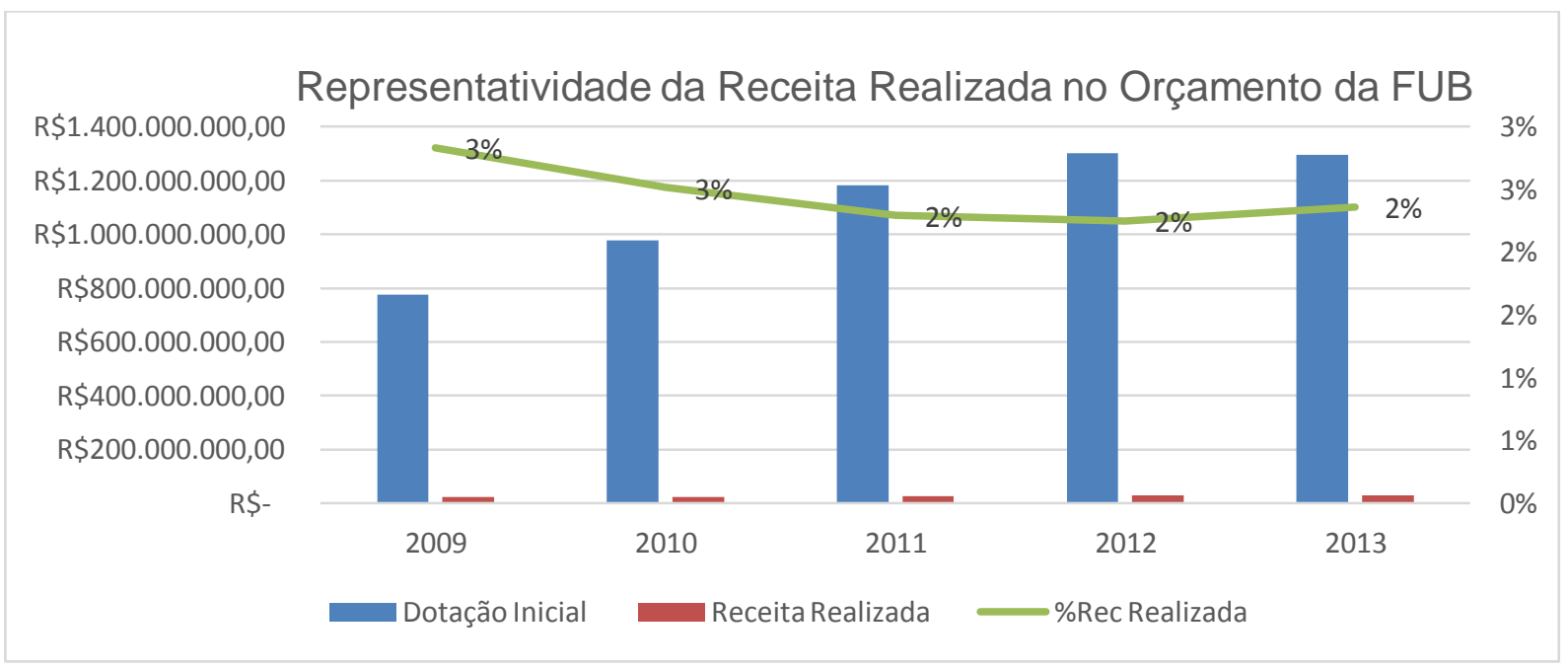

Fonte: Siga Brasil-Senado Federal e SIAFI, 2015.

Elaborada pela autora

\subsection{ESTUDO DO CUSTO DE OPORTUNIDADE}

Inicia-se nova fase da pesquisa aplicando-se o conceito do Custo de Oportunidade, ao confrontar com a alternativa de uma segunda oportunidade de benefício não aproveitada.

O estudo mostra que apenas $13 \%$ do corpo funcional são beneficiados com a remuneração não pecuniária. Os servidores beneficiados têm moradia na adjacência da Universidade, pagam aluguel com valor subsidiado, bem como as vantagens atreladas ao benefício, que são:

1) redução de gastos com combustível;

2) redução de gasto com manutenção de veículo;

3) ausência de estresse no trânsito;

4) ausência de estresse com transporte coletivo ineficiente;

5) tempo transcorrido entre a saída de casa e a chegada ao trabalho;

6) qualidade de vida.

Tal situação difere daquela que enfrentam os outros $87 \%$ do corpo funcional:

1) residem a grande distância do trabalho;

2) pagam aluguel ou financiamento de imóvel;

3) arcam com despesas relativas ao percurso moradia-trabalho;

4) para chegada ao trabalho são disponibilizadas de uma a três horas de antecedência do horário de trabalho, maior parte desse tempo é 
destinado ao período no trânsito;

5) a maioria dos servidores traz alimentação de casa ou se alimenta na adjacência, onde o preço é mais elevado ou ainda enfrenta filas intermináveis no Restaurante Universitário;

6) no retorno à casa, são gastas de uma a três horas no enfrentamento do trânsito.

Ao verificar as diferenças citadas, surgiu a ideia de que uma população maior poderia ser alcançada com o benefício, ao menos para suprir as despesas a mais que a população de $87 \%$ dos servidores da FUB arcam sem receber nenhum tipo de benefício. Por isso, o estudo é voltado para testar teorias a viabilidade de alternativas para contemplar um maior número de pessoas.

\subsubsection{Receita proveniente dos aluguéis adotados pela FUB - 2009 a 2013}

Segundo a SGP, anualmente é realizada licitação para a escolha de uma empresa com a finalidade de avaliar os imóveis da FUB. O valor de aluguel sugerido pela empresa licitada é transferido aos futuros e atuais ocupantes dos imóveis da FUB. Seguindo o roteiro dos objetivos específicos, foi realizada análise documental, identificando a quantidade, o metro quadrado, tipo de apartamento por número de quartos, o valor do aluguel sugerido pela empresa avaliadora, em tese adotado pela FUB, no período de 2009 a 2013.

Tabela 12: Média do aluguel adotado pela FUB - valores nominais

$\mathrm{R} \$ 1,00$

\begin{tabular}{|l|c|c|r|}
\hline \multicolumn{3}{|c|}{ Exercício 2009 } \\
\hline Apartamento & Quantidade & $M^{2}$ médio & Média aluguel efetivo \\
\hline 1 quarto & 9 & 89 & $2.858,67$ \\
\hline 2 quartos & 652 & 93,88 & $1.290,04$ \\
\hline 3 quartos & 741 & 136,82 & 860,78 \\
\hline 4 quartos & 126 & 182,89 & $1.901,28$ \\
\hline Salas e lojas & 105 & 50,56 & 801,08 \\
\hline \multicolumn{3}{|c|}{ Exercício 2010 } \\
\hline Apartamento & & $M^{2}$ médio & Média Aluguel Efetivo \\
\hline 1 quarto & Quantidade & 89 & $3.054,00$ \\
\hline 2 quartos & 9 & 93,88 & $1.409,67$ \\
\hline
\end{tabular}


Tabela 12: Média do aluguel adotado pela FUB - valores nominais

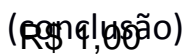

\begin{tabular}{|c|c|c|c|}
\hline 3 quartos & 741 & 136,82 & 887,49 \\
\hline 4 quartos & 126 & 182,89 & $2.015,69$ \\
\hline Salas e lojas & 105 & 50,56 & 865,12 \\
\hline \multicolumn{4}{|c|}{ Exercício 2011} \\
\hline Apartamento & Quantidade & $\mathrm{M}^{2}$ médio & Média Aluguel Efetivo \\
\hline 1 quarto & 9 & 89 & 3568,33 \\
\hline 2 quartos & 652 & 93,88 & 1654,28 \\
\hline 3 quartos & 741 & 136,82 & 991,85 \\
\hline 4 quartos & 126 & 182,89 & 2304,91 \\
\hline Salas e Lojas & 105 & 50,56 & 1014,71 \\
\hline \multicolumn{4}{|c|}{ Exercício 2012} \\
\hline Apartam. & Quantidade & $\mathrm{M}^{2}$ médio & Média Aluguel Efetivo \\
\hline 1 quarto & 9 & 89 & $3.070,00$ \\
\hline 2 quartos & 652 & 93,88 & $1.643,58$ \\
\hline 3 quartos & 741 & 136,82 & 989,46 \\
\hline 4 quartos & 126 & 182,89 & $2.352,66$ \\
\hline Salas e Lojas & 105 & 50,56 & 958,87 \\
\hline \multicolumn{4}{|c|}{ Exercício 2013} \\
\hline Apartam. & Quantidade & $\mathrm{M}^{2}$ médio & Média de Aluguel Efetivo \\
\hline 1 quarto & 9 & 89 & $3.534,49$ \\
\hline 2 quartos & 652 & 93,88 & $1.905,18$ \\
\hline 3 quartos & 741 & 136,82 & $1.093,15$ \\
\hline 4 quartos & 126 & 182,89 & $2.619,58$ \\
\hline Salas e Lojas & 105 & 50,56 & $1.162,43$ \\
\hline
\end{tabular}

Fonte: SGP, 2015.

Elaborada pela autora

Ao analisar os valores dos alugueis adotados pela FUB nos cinco exercícios, verifica-se que há maior evolução nos apartamentos de 1 quarto, uma média de 14 $\%$ de um exercício para o outro. Seguido do aparamento de 2 quartos que teve uma média de aumento de $12 \%$, os apartamentos de 3 e 4 quartos e as salas apresentaram uma média de $11 \%$ de aumento de um exercício para o outro. Observa-se que a ocorrência do aumento nos valores do aluguel foi provocada pelos imóveis da carteira imobiliária destinada a terceiro, pois os valores dos termos de ocupação de imóveis destinados aos servidores, apresentavam-se inalterados no período de 2009 a 2013. 


\subsubsection{Valor do aluguel de mercado:}

Os valores dos aluguéis são definidos a partir de avaliações realizadas anualmente, e as condições obedecem à Lei 8.245, de 18/10/1991 - Lei do Inquilinato. Assim, do total de imóveis da instituição, 1.528 são residenciais, desses 679 são destinados a servidores. Há 176 imóveis comerciais, desses 71 são permissões especiais concedidas a diferentes órgãos da FUB, com isenção total de ônus em aluguel e condomínio.

Conforme parecer da Procuradoria Jurídica da Fundação Universidade de Brasília, os imóveis da FUB não se enquadram como funcionais, pois constituem o patrimônio da Fundação e sua renda se destina a auxiliar na manutenção da Universidade.

Os documentos utilizados para aplicação da pesquisa foram os Boletins da Conjuntura Imobiliária do Sindicato da Habitação do DF, emitidos nos exercícios de 2010, 2011, 2012 e 2013. O SECOVI-DF utiliza amostragem feita por meio de levantamento de dados nas imobiliárias que atuam no DF. Assim, os dados divulgados servem como insumo para pesquisa e análise da conjuntura do mercado imobiliário no Distrito Federal.

Foram classificados os dados dos imóveis da FUB, relativos à localização, metragem do imóvel, número de dormitório e garagem:

1) para estimar o valor de aluguel a preço de mercado, foram utilizados os dados dos Boletins Imobiliários do Secovi/DF, referentes aos preços do metro quadrado para locação e relacionados com as informações dos apartamentos da FUB, como metro quadrado, localização, tipo de apartamento, dos imóveis residenciais e comerciais da FUB, classificados em cada exercício separadamente, de 2009 a 2013;

2) para estimar o valor de venda a preço de mercado, também foram utilizados os dados dos Boletins Imobiliários do Secovi/DF, relativos aos preços do metro quadrado para venda e relacionados com as informações dos apartamentos da FUB, como metro quadrado, localização, tipo de apartamento, dos imóveis residenciais e comerciais da FUB, classificados em cada exercício separadamente, de 2009 a 2013;

3) os resultados são apresentados em relação aos valores de aluguel e de venda, a preço de mercado, nos diferentes exercícios, para melhor exposição, análise e comparação. 
Os imóveis residenciais da FUB são localizados no Plano Piloto, Asa Norte e Setor Hoteleiro Norte, e os comerciais destinados a locação situam-se na Asa Norte e na Asa Sul. Os imóveis residenciais são compostos por apartamentos com 1, 2, 3 e 4 dormitórios. Os comercias são compostos por salas e lojas.

A localização dos imóveis residenciais segue detalhadamente a tabela abaixo: Tabela 13: Imóveis residenciais destinados à moradia de servidores (continua)

\begin{tabular}{|c|c|c|c|c|c|}
\hline & 1 quarto & 2 quartos & 3 quartos & 4 quartos & Total \\
\hline Colina A & & 0 & 18 & & 18 \\
\hline Colina B & & 18 & 0 & & 18 \\
\hline Colina C & & 18 & 0 & & 18 \\
\hline Colina D & & 0 & 18 & & 18 \\
\hline Colina E & & 6 & 36 & 6 & 48 \\
\hline Colina F & & 6 & 24 & 6 & 36 \\
\hline Colina G & & 12 & 24 & 12 & 48 \\
\hline Colina $\mathrm{H}$ & & 12 & 24 & 12 & 48 \\
\hline Colina I & & 6 & 24 & 6 & 36 \\
\hline Colina J & & 12 & 24 & 12 & 48 \\
\hline Colina K & & 18 & & & \\
\hline SQN $107 \mathrm{H}$ & & 0 & 0 & 2 & 2 \\
\hline SQN $109 \mathrm{H}$ & & 0 & 20 & & 20 \\
\hline SQN 109I & & 36 & 0 & & 36 \\
\hline SQN $109 \mathrm{~J}$ & & 72 & 0 & & 72 \\
\hline SQN 205 C & & 0 & 36 & & 36 \\
\hline SQN $205 \mathrm{G}$ & & 0 & 36 & & 36 \\
\hline SQN $205 \mathrm{H}$ & & 0 & 36 & & 36 \\
\hline SQN $205 \mathrm{~L}$ & & 0 & 36 & & 36 \\
\hline SQN $206 \mathrm{~A}$ & & 0 & 36 & & 36 \\
\hline SQN 206 B & & 0 & 36 & & 36 \\
\hline SQN $206 \mathrm{~F}$ & & 0 & 36 & & 36 \\
\hline SQN $206 \mathrm{~J}$ & & 0 & 36 & & 36 \\
\hline SQN $206 \mathrm{~K}$ & & 0 & 36 & & 36 \\
\hline SQN $212 \mathrm{~A}$ & & 65 & 18 & & 83 \\
\hline SQN $212 \mathrm{C}$ & & 49 & 0 & & 49 \\
\hline SQN 212 D & & 0 & 11 & & 11 \\
\hline SQN $212 \mathrm{E}$ & & 0 & 20 & 8 & 28 \\
\hline SQN $212 \mathrm{~F}$ & & 0 & 18 & 8 & 26 \\
\hline SQN $212 \mathrm{G}$ & & 29 & 4 & & 33 \\
\hline SQN $212 \mathrm{H}$ & & 3 & 0 & & 3 \\
\hline SQN 212 I & & 0 & 21 & & 21 \\
\hline SQN $212 \mathrm{~J}$ & 3 & 2 & 0 & & 5 \\
\hline SQN $212 \mathrm{~K}$ & & 8 & 0 & & 8 \\
\hline
\end{tabular}


Tabela 13: Imóveis residenciais destinados à moradia de servidores

(conclusão)

\begin{tabular}{|c|c|c|c|c|c|}
\hline & 1 quarto & 2 quartos & 3 quartos & 4 quartos & Total \\
\hline SQN $214 \mathrm{~A}$ & & 0 & 25 & & 25 \\
\hline SQN 214 B & & 27 & & & 0 \\
\hline SQN $214 \mathrm{C}$ & & 43 & 0 & & 43 \\
\hline SQN $214 \mathrm{D}$ & & 40 & 0 & & 40 \\
\hline SQN $214 \mathrm{E}$ & & 29 & 0 & & 29 \\
\hline SQN $214 \mathrm{~F}$ & & 36 & 0 & & 36 \\
\hline SQN 214 G & & 27 & 4 & & 35 \\
\hline SQN $214 \mathrm{H}$ & & 39 & 0 & & 39 \\
\hline SQN 214 I & & 0 & 27 & & 27 \\
\hline SQN $214 \mathrm{~J}$ & & 0 & 27 & & 27 \\
\hline SQN $214 \mathrm{~K}$ & & 39 & 0 & & 39 \\
\hline SQN $310 \mathrm{E}$ & & 0 & 6 & 11 & 17 \\
\hline SQN $310 \mathrm{~F}$ & & 0 & 12 & 11 & 11 \\
\hline SQN $310 \mathrm{G}$ & & 0 & 0 & 20 & 20 \\
\hline SQN $310 \mathrm{~J}$ & & 0 & 0 & 11 & 11 \\
\hline SQN $310 \mathrm{~K}$ & & 0 & 0 & 1 & 1 \\
\hline SHTN BL F & 6 & 0 & 12 & & 6 \\
\hline Total & 9 & 652 & 741 & 126 & 1.528 \\
\hline
\end{tabular}

Fonte: Inventário Patrimonial de Imóveis da FUB, 2012 e Secretaria de Gestão Patrimonial-SGP, 2015.

Com base nos relatórios fornecidos pela SGP, a quantidade de imóveis residenciais na carteira imobiliária atualmente é de 1528 unidades. Segundo o Inventário Patrimonial de 2012, o estado de conservação dos imóveis varia entre muito bom, bom, regular e ruim, a maioria necessitando de obras de reparos, especialmente os situados na Colina.

$\mathrm{Na}$ Tabela 14, foram relacionados os valores médios do aluguel efetivo adotado pela instituição e o valor de aluguel a preço de mercado dos exercícios de 2009 a 2013. Para visualização da discrepância de valor, acrescentou-se também o resultado da diferença dos aluguéis:

Tabela 14: Diferença do aluguel adotado pela FUB e aluguel de mercado - Em Reais, valores nominais

\begin{tabular}{|l|c|c|c|}
\hline \multicolumn{4}{|c|}{ Período de 2009 a 2013 } \\
\hline \multicolumn{1}{|c|}{ Apartamento } & Média aluguel adotado & Média aluguel mercado & Diferença \\
\hline 1 quarto & $3.079,80$ & $2.679,03$ & 400,77 \\
\hline 2 quartos & $1.580,55$ & $2.579,08$ & 998,53 \\
\hline 3 quartos & 964,55 & $3.256,34$ & $2.291,79$ \\
\hline 4 quartos & $2.376,83$ & $4.389,34$ & $2.012,51$ \\
\hline
\end{tabular}




\begin{tabular}{l|c|c|c} 
salas e lojas & 960,44 & $1.993,46$ & $1.033,03$ \\
\hline Fonte: SGP e SECOVI-DF, 2015. (Elaborada pela autora)
\end{tabular}

Os valores de aluguel dos apartamentos de 1 quarto, adotados pela FUB, se mostram mais elevados que os de mercado. A justificativa se dá tendo em vista que os apartamentos de 1 quarto da FUB se diferenciam por estarem localizados em hotel e outros por apresentarem metragem superior aos de mercado.

Figura 09: Diferença entre o aluguel adotado pela FUB e o aluguel valor de mercado - exercício 2009

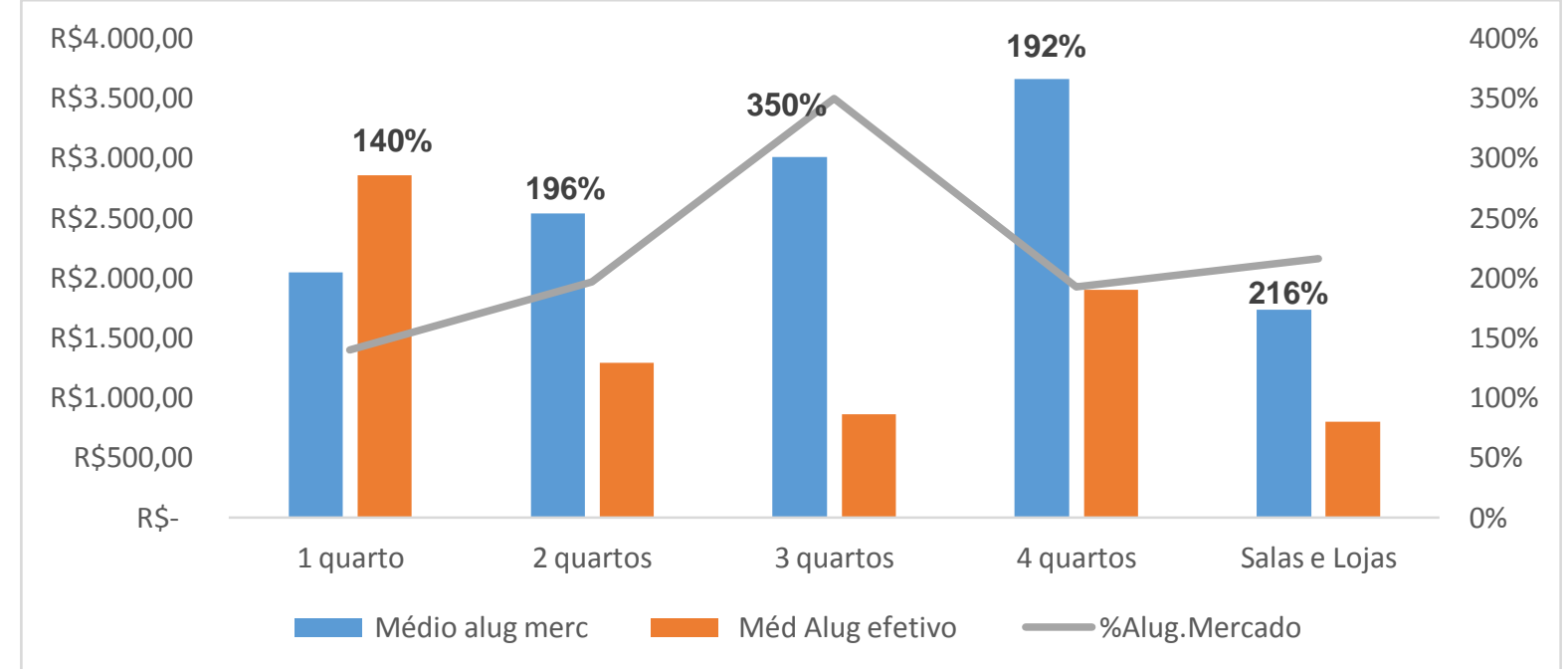

Fonte: SGP/SECOVI - DF, 2015.

Elaborada pela autora

Observa-se que o valor dos aluguéis adotado pela FUB é menor que os aluguéis do mercado, com exceção do valor de aluguel do apartamento de um quarto, que supera o preço de mercado. Verifica-se uma grande diferença a menor entre o valor de aluguel adotado pela FUB em comparação ao de mercado.

Figura 10: Diferença entre o aluguel adotado pela FUB e o aluguel valor de mercado - exercício 2010

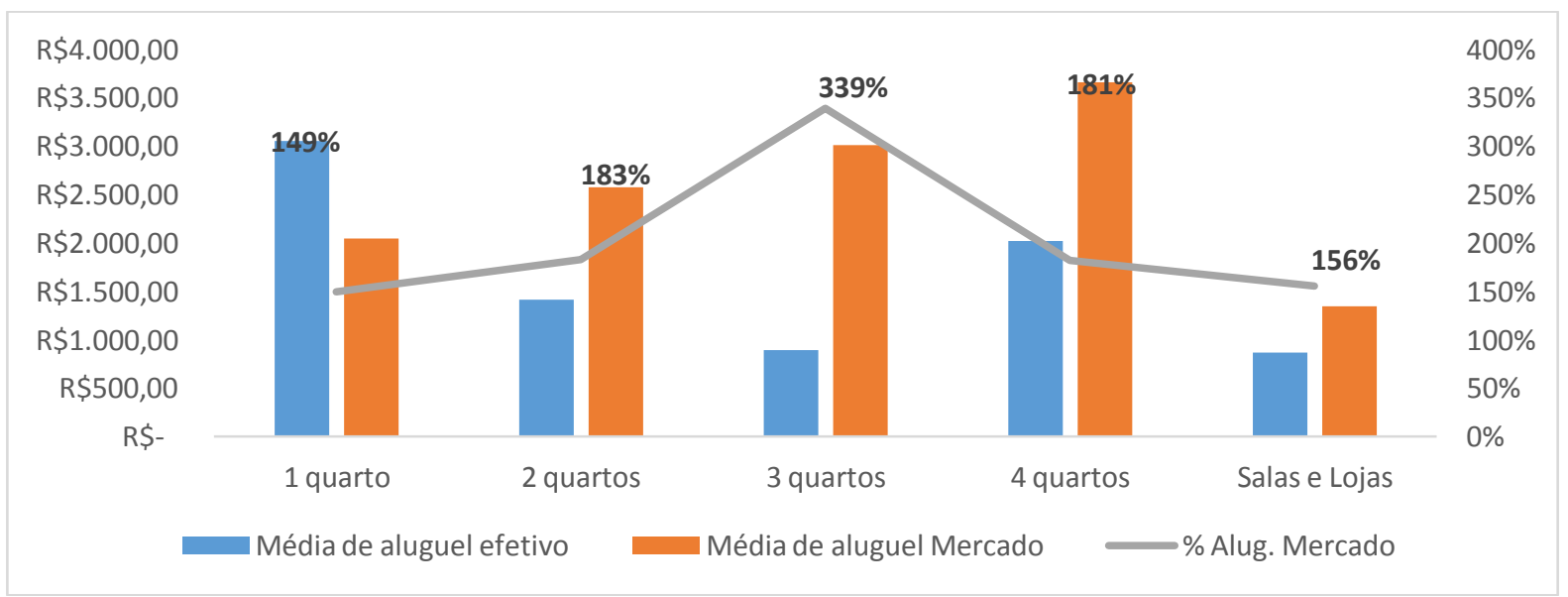

Fonte: SGP/SECOVI - DF, 2015.

Elaborada pela autora 
No ano 2010, os aluguéis a preço de mercado continuaram altos, mas verificou-se uma sutil redução na diferença entre os aluguéis. Os valores de aluguel dos apartamentos de um quarto continuaram acima do preço de mercado.

Figura 11: Diferença entre o aluguel adotado pela FUB e o aluguel valor de mercado - exercício 2011

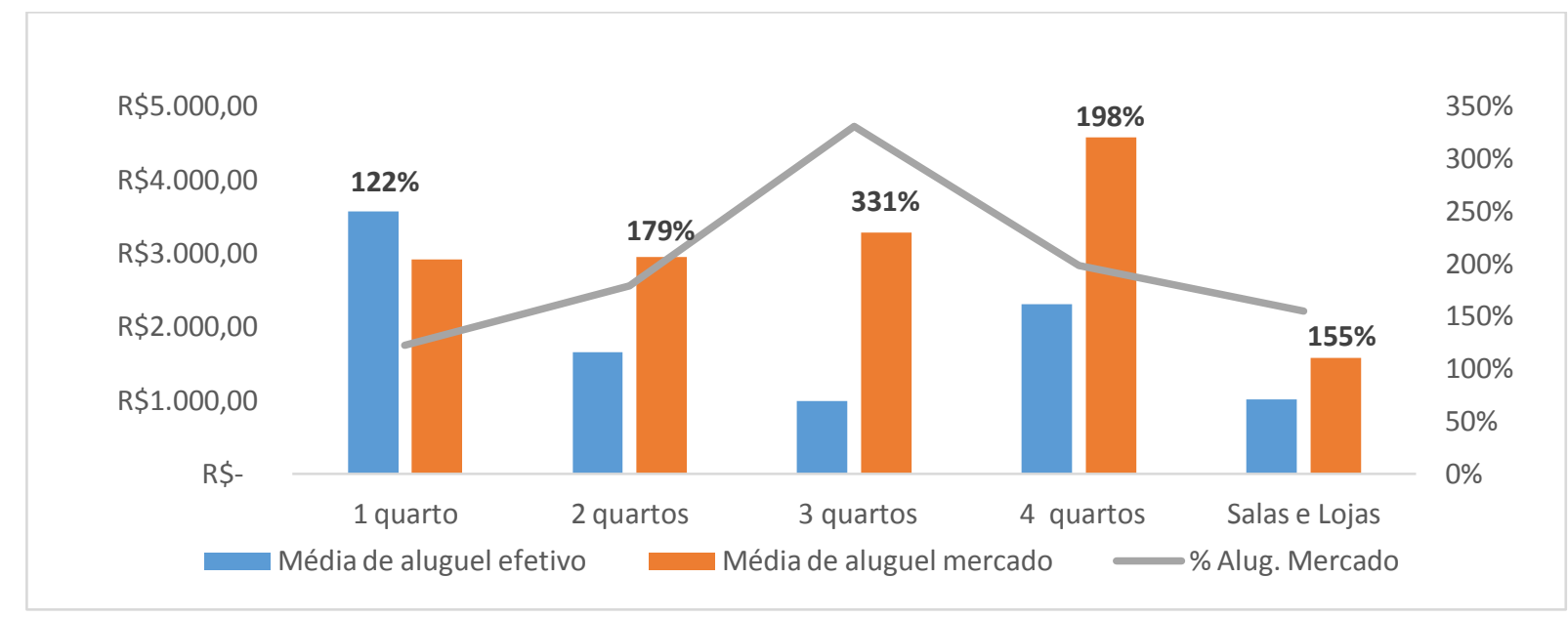

Fonte: SGP/SECOVI-DF, 2015.

Elaborada pela autora

Nota-se uma queda maior na diferença entre o valor de aluguel adotado pela FUB e o valor de aluguel a preço de mercado. Entretanto, ocorreu um aumento na diferença nos valores de aluguel de salas e lojas.

Figura 12: Diferença entre o aluguel adotado pela FUB e o aluguel valor de mercado - exercício 2012

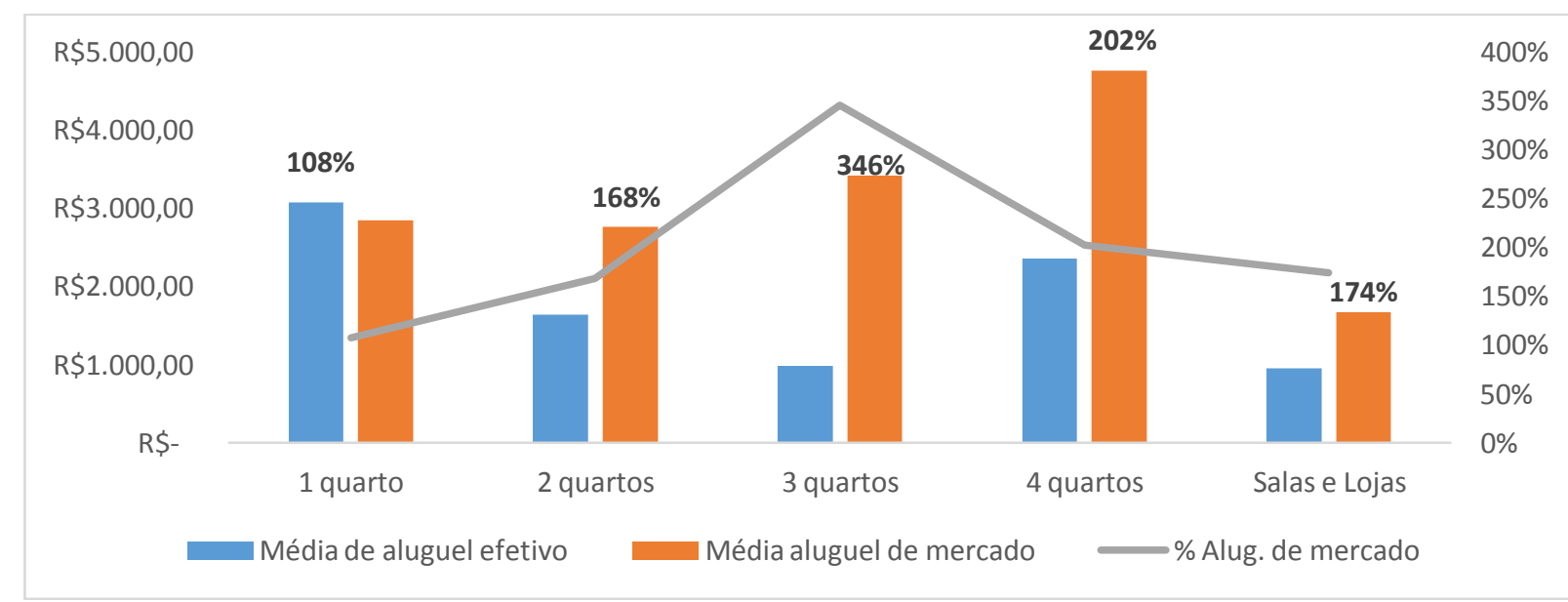

Fonte: SGP/SECOVI-DF, 2015

Elaborada pela autora

Em 2012, os aluguéis adotados pela FUB continuaram abaixo do valor de 
mercado.

Figura 13: Diferença entre o aluguel adotado pela FUB e o aluguel valor de mercado - exercício 2013

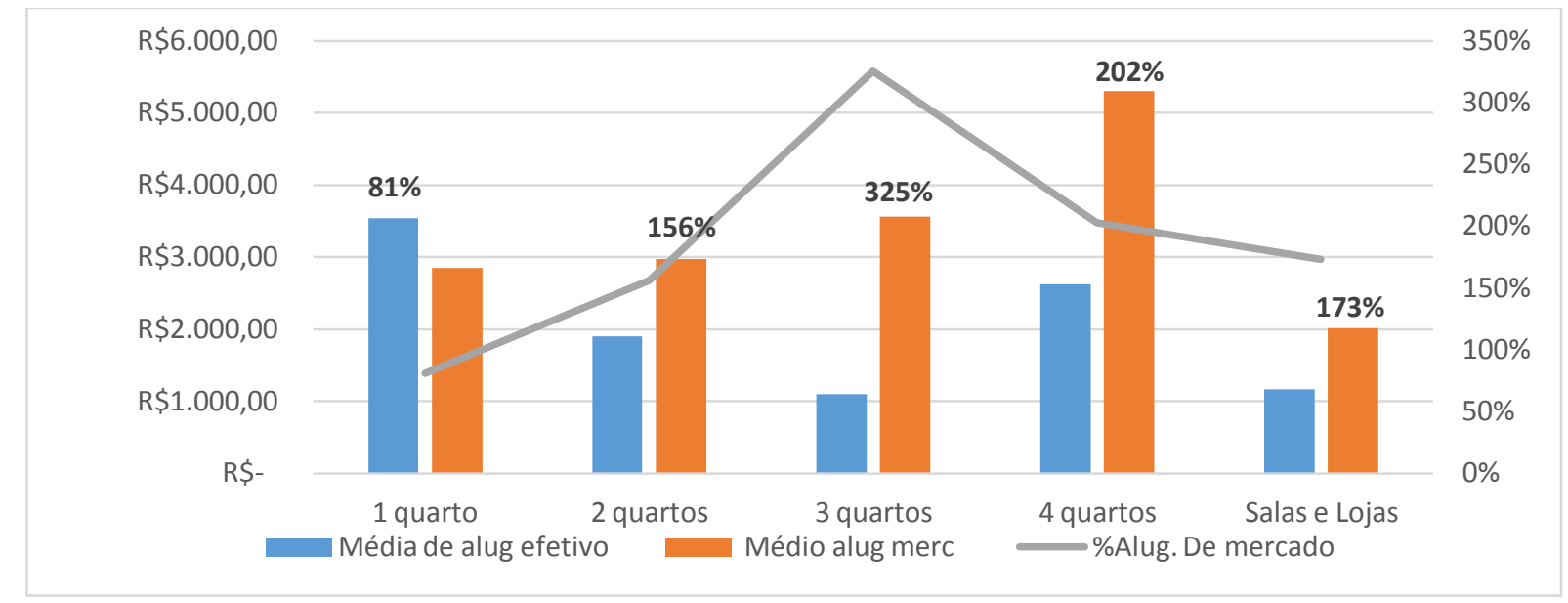

Fonte: SGP/SECOVI - DF, 2015.

Elaborada pela autora

Em 2013, o gráfico se manteve: os apartamentos de um quarto são oferecidos pela FUB com o preço acima do de mercado, tendo em vista os apartamentos de um quarto serem diferenciados, alguns possuem metragem maior do que os de mercado e outros são localizados em hotel.

Figura 14: Representação da receita potencial em relação à dotação orçamentária

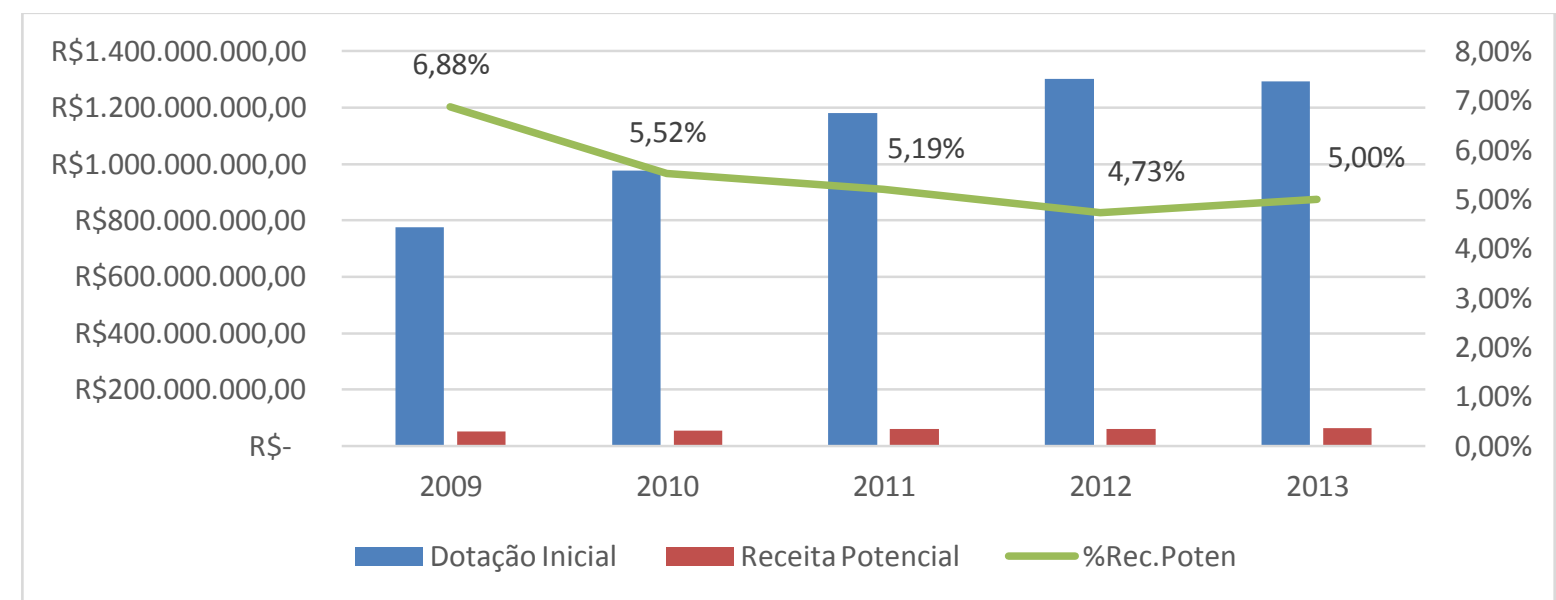

Fonte: SECOVI e Siga Brasil-Senado Federal, 2015.

Elaborada pela autora

A representatividade da Receita Potencial de Aluguel, em relação ao orçamento da FUB, é maior que a Receita Realizada pela FUB. 
Em 2013 a dotação orçamentária inicial foi de $R \$ 1.294 .373 .010,00$. A receita potencial de aluguel em 2013 foi de $R \$ 64.707 .607,32$ e a receita realizada no mesmo exercício foi de $R \$ 30.543 .705,63$.

A Figura 14 mostra que a Receita Potencial representa em média $5,46 \%$ da Dotação Inicial Orçamentária, ao passo que a Receita Realizada representa $2 \%$ (Figura 8).

\subsubsection{Análises de alternativas da gestão do patrimônio imobiliário}

$\mathrm{Na}$ terceira etapa, foram utilizados os resultados dos valores de aluguel a preço de mercado e os valores de venda a preço de mercado no estudo do custo de oportunidade aplicado ao sistema imobiliário da FUB. Com isso, objetivou-se estimar a economicidade de uma outra opção ou verificar o custo/benefício, na tentativa de atingir um resultado mais favorável para a instituição e um resultado igualitário para o corpo funcional.

Nesse sentido, foram apresentadas as alternativas A e B como forma de alternativas de gestão do patrimônio imobiliário:

Alternativa A: A Fundação Universidade de Brasília aluga os imóveis a preço de mercado.

Para desenvolver a pesquisa, consultamos os dados referentes ao valor do metro quadrado do imóvel para aluguel, retirada a informação do Boletim Imobiliário da SECOVI, emitido nos exercícios de 2010 a 2013. Foram utilizados os dados do Boletim de 2010 do SECOVI - DF para calcular o valor de mercado dos imóveis da FUB, referente ao exercício de 2009, em decorrência do Sindicato de Habitação do DF não ter emitido Boletim relativo ao exercício de 2009.

A Potencial Receita de Aluguel dos apartamentos residenciais foi aferida pela multiplicação do metro quadrado dos imóveis da FUB com o valor de mercado do metro quadrado para locação, de imóveis residenciais e de imóveis comerciais, retirados do Boletim Imobiliário da SECOVI.

É importante ressaltar que a FUB utiliza a receita resultante das atividades imobiliárias com despesas gerais da Universidade. Assim, na alternativa A, considera-se que a receita dos imóveis da FUB é proveniente dos aluguéis a preço de mercado, da qual são deduzidas as despesas gerais da instituição e as despesas 
de manutenção dos imóveis, resultando na Receita Potencial Líquida.

Alternativa A:

Equação: Receita Potencial - Despesas Gerais da FUB - Manutenção = Receita Potencial Líquida

É nesse estágio da Hipótese A que incide o desafio, o processo de escolha, o trade-off. A proposta é dividir a Receita Potencial Líquida pela quantidade de servidores da FUB, docentes e técnicos administrativos. O resultado aferido é objeto de análise para verificar se descobrimos uma maneira de contemplar o benefício de moradia, com o qual apenas $13 \%$ dos servidores são favorecidos, para beneficiar o máximo possível de servidores.

Equação: Receita Potencial Líquida / Quantidade de Servidores da FUB = Complemento de Renda

De acordo com o Sistema Integrado de Administração de Recursos Humanos - SIAPE, a quantidade de servidores ativos da FUB nos exercícios de 2009 a 2013 era de:

- $2009=5.504$ servidores

- $2010=5.412$ servidores

- $2011=5.319$ servidores

- $2012=5.226$ servidores

- $2013=5.122$ servidores

Para desenvolver a pesquisa, consultamos os dados relativos ao valor do metro quadrado do imóvel para aluguel, retirada a informação do Boletim Imobiliário da SECOVI emitido no exercício de 2010 a 2013.

Tabela 15: Valor de metro quadrado de locação e de venda

(continua)

\begin{tabular}{|c|c|c|c|}
\hline \multicolumn{4}{|c|}{2010} \\
\hline Tipo de apartamento & Valor m² locação (R\$) & Valor $\mathrm{m}^{2}$ venda $(\mathrm{R} \$)$ & Ano do Boletim SECOVI \\
\hline 1 quarto & 23 & 9264 & 2010 \\
\hline 2 quartos & 27 & 6513 & 2010 \\
\hline 3 quartos & 22 & 7131 & 2010 \\
\hline 4 quartos & 20 & 9056 & 2010 \\
\hline Salas e lojas & $24 / 35 / 41$ & $6491 / 7125 / 9870$ & 2010 \\
\hline \multicolumn{4}{|c|}{2011} \\
\hline Tipo de apartamento & Valor m² locação (R\$) & Valor $\mathrm{m}^{2}$ venda $(\mathrm{R} \$)$ & Ano do Boletim SECOVI \\
\hline 1 quarto & $32 / 34$ & 8067 & 2011 \\
\hline 2 quartos & 31 & 8250 & 2011 \\
\hline 3 quartos & 24 & 7240 & 2011 \\
\hline 4 quartos & 25 & 8684 & 2011 \\
\hline Salas e lojas & $30 / 42 / 45$ & $5051 / 9000 / 9784$ & 2011 \\
\hline
\end{tabular}


Tabela 15: Valor de metro quadrado de locação e de venda

(conclusão)

\begin{tabular}{|c|c|c|c|}
\hline \multicolumn{4}{|c|}{2012} \\
\hline Tipo de apartamento & Valor m² locação $(\mathrm{R} \$)$ & Valor $\mathrm{m}^{2}$ venda $(\mathrm{R} \$)$ & Ano do Boletim SECOVI \\
\hline 1 quarto & 32 & 8889 & 2012 \\
\hline 2 quartos & 29 & 8673 & 2012 \\
\hline 3 quartos & 25 & 8362 & 2012 \\
\hline 4 quartos & 26 & 9050 & 2012 \\
\hline Salas e lojas & $45 / 45 / 53$ & $6167 / 10323 / 10940$ & 2012 \\
\hline \multicolumn{4}{|c|}{2013} \\
\hline Tipo de apartamento & Valor m² locação $(\mathrm{R} \$)$ & Valor $\mathrm{m}^{2}$ venda $(\mathrm{R} \$)$ & Ano do Boletim SECOVI \\
\hline 1 quarto & 32 & 9310 & 2013 \\
\hline 2 quartos & 31 & 8948 & 2013 \\
\hline 3 quartos & 26 & 8741 & 2013 \\
\hline 4 quartos & 29 & 10000 & 2013 \\
\hline Salas e lojas & $37 / 40$ & $5556 / 1086 / 1585$ & 2013 \\
\hline
\end{tabular}

Fonte: SECOVI - DF, 2015 (Elaborado pela autora)

Na tabela 15, foram detalhados os valores do metro quadrado para aluguel e o valor de venda, relativos a cada tipo de apartamento da FUB e a cada exercício, conforme Boletins do SECOVI-DF.

Após relacionar os dados dos imóveis da FUB com os dados do SECOVI-DF, foi encontrado o valor da Receita Potencial de Aluguel dos imóveis.

Tabela 16: Receita de aluguel potencial dos imóveis da FUB - 2009

\begin{tabular}{|l|r|r|r|r|r|}
\hline \multicolumn{1}{|c|}{ Apartam. } & Quantidade & $\mathrm{M}^{2}$ médio & $\begin{array}{c}\text { Médio aluguel } \\
\text { mercado }(\mathrm{R} \$)\end{array}$ & $\begin{array}{r}\text { Receita potencial (mês) } \\
(\mathrm{R} \$)\end{array}$ & $\begin{array}{c}\text { Receita potencial (ano) } \\
(\mathrm{R} \$)\end{array}$ \\
\hline 1 quarto & 9 & 89,00 & $2.047,00$ & $18.423,00$ & $221.076,00$ \\
\hline 2 quartos & 652 & 93,88 & $2.534,73$ & $1.596 .877,47$ & $19.162 .529,64$ \\
\hline 3 quartos & 741 & 136,82 & $3.010,06$ & $2.194 .330,16$ & $26.331 .961,92$ \\
\hline 4 quartos & 126 & 182,89 & $3.657,79$ & $460.881,20$ & $5.530 .574,40$ \\
\hline $\begin{array}{l}\text { Salas e } \\
\text { Lojas }\end{array}$ & 105 & 50,56 & $1.276,47$ & $134.029,00$ & $1.608 .348,00$ \\
\hline Total & 1.633 & & & $4.404 .540,83$ & $52.854 .489,96$ \\
\hline
\end{tabular}

Fonte: SECOVI - DF, 2015. (Elaborada pela autora)

Tabela 17: Receita de aluguel potencial dos imóveis da FUB - 2010

\begin{tabular}{|l|r|r|r|r|r|}
\hline \multicolumn{1}{|c|}{ Apartam. } & Quantidade & \multicolumn{1}{|c|}{$\mathrm{M}^{2}$ médio } & $\begin{array}{c}\text { Médio aluguel } \\
\text { mercado(R } \$)\end{array}$ & $\begin{array}{c}\text { Receita potencial } \\
\text { (mês) }(\mathrm{R} \$)\end{array}$ & $\begin{array}{c}\text { Receita potencial (ano) } \\
\text { (R\$) }\end{array}$ \\
\hline 1 quarto & 9 & 89,00 & $2.047,00$ & $18.423,00$ & $221.076,00$ \\
\hline 2 quartos & 652 & 93,88 & $2.573,58$ & $1.641 .944,04$ & $19.703 .328,48$ \\
\hline 3 quartos & 741 & 136,82 & $3.010,06$ & $2.194 .333,74$ & $26.332 .004,88$ \\
\hline 4 quartos & 126 & 182,89 & $3.657,79$ & $460.881,54$ & $5.530 .578,48$ \\
\hline $\begin{array}{l}\text { Salas } \\
\text { Lojas }\end{array}$ & 105 & 50,56 & $1.733,33$ & $181.999,65$ & $2.183 .995,80$ \\
\hline Total & 1.633 & & & $4.497 .581,97$ & $53.970 .983,64$ \\
\hline
\end{tabular}

Fonte: SECOVI - DF, 2015.

Elaborada pela autora 
Tabela 18: Receita de aluguel potencial dos imóveis da FUB - 2011

\begin{tabular}{|l|r|r|r|r|r|}
\hline \multicolumn{1}{|c|}{ Apartam. } & Quantidade & $\mathrm{M}^{2}$ médio & $\begin{array}{c}\text { Média aluguel } \\
\text { mercado }(\mathrm{R} \$)\end{array}$ & $\begin{array}{r}\text { Receita potencial/mês } \\
(\mathrm{R} \$)\end{array}$ & $\begin{array}{c}\text { Receita potencial/ano } \\
(\mathrm{R} \$)\end{array}$ \\
\hline 1 quarto & 9 & 89,00 & $2.918,66$ & $26.268,00$ & $315.216,00$ \\
\hline 2 quartos & 652 & 93,88 & $2.954,85$ & $1.885 .195,25$ & $2.622 .343,00$ \\
\hline 3 quartos & 741 & 136,82 & $3.283,70$ & $2.393 .814,72$ & $28.725 .776,64$ \\
\hline 4 quartos & 126 & 182,89 & $4.572,23$ & $576.101,50$ & $6.913 .218,00$ \\
\hline $\begin{array}{c}\text { Salas } \\
\text { Lojas }\end{array}$ & 105 & 50,56 & $1.014,71$ & $231.393,00$ & $2.776 .716,00$ \\
\hline Total & 1.633 & & $4.744,15$ & $5.112 .772,47$ & $61.353 .269,64$ \\
\hline
\end{tabular}

Fonte: SECOVI - DF, 2015.

Elaborada pela autora

Tabela 19: Receita de aluguel potencial dos imóveis da FUB - 2012

\begin{tabular}{|l|r|r|r|r|r|}
\hline \multicolumn{1}{|c|}{ Apartam. } & Quantidade & \multicolumn{1}{c|}{$\mathrm{M}^{2}$ médio } & $\begin{array}{c}\text { Média aluguel } \\
\text { mercado }(\mathrm{R} \$)\end{array}$ & $\begin{array}{c}\text { Receita potencial } \\
(\mathrm{mês})(\mathrm{R} \$)\end{array}$ & $\begin{array}{c}\text { Receita potencial (ano) } \\
(\mathrm{R} \$)\end{array}$ \\
\hline 1 quarto & 9 & 89,00 & $2.848,00$ & $25.632,00$ & $307.584,00$ \\
\hline 2 quartos & 652 & 93,88 & $2.764,22$ & $1.763 .572,36$ & $21.162 .868,32$ \\
\hline 3 quartos & 741 & 136,82 & $3.420,52$ & $2.493 .559,08$ & $29.922 .708,96$ \\
\hline 4 quartos & 126 & 182,89 & $4.755,12$ & $599.145,12$ & $7.189 .741,44$ \\
\hline $\begin{array}{l}\text { Salas } \\
\text { Lojas }\end{array}$ & 105 & 50,56 & $2.285,56$ & $239.983,80$ & $2.879 .805,60$ \\
\hline Total & 1.633 & & & $5.121 .892,36$ & $61.462 .708,32$ \\
\hline
\end{tabular}

Fonte: SECOVI - DF, 2015.

Elaborada pela autora

Tabela 20: Receita de aluguel potencial dos imóveis da FUB - 2013

\begin{tabular}{|l|r|r|r|r|r|}
\hline Apartam. & Quantidade & \multicolumn{1}{|c|}{$\mathrm{M}^{2}$ médio } & $\begin{array}{c}\text { Média aluguel } \\
\text { mercado }(\mathrm{R} \$)\end{array}$ & \multicolumn{1}{c|}{$\begin{array}{c}\text { Receita potencial } \\
(\mathrm{mês})(\mathrm{R} \$)\end{array}$} & $\begin{array}{c}\text { Receita potencial (Ano) } \\
(\mathrm{R} \$)\end{array}$ \\
\hline 1 quarto & 9 & 89,00 & $2.848,00$ & $25.632,00$ & $307.584,00$ \\
\hline 2 quartos & 652 & 93,88 & $2.968,43$ & $1.893 .858,34$ & $22.726 .300,08$ \\
\hline 3 quartos & 741 & 136,82 & $3.557,39$ & $2.593 .337,31$ & $31.120 .047,72$ \\
\hline 4 quartos & 126 & 182,89 & $5.303,79$ & $668.277,54$ & $8.019 .330,48$ \\
\hline $\begin{array}{l}\text { Salas } \mathrm{e} \\
\text { Lojas }\end{array}$ & 105 & 50,56 & $2.011,36$ & $211.192,80$ & $62.173 .262,28$ \\
\hline Total & 1.633 & & & $5.392 .297,99$ & $62.173 .262,28$ \\
\hline
\end{tabular}

Fonte: SECOVI - DF, 2015.

Elaborada pela autora

$\mathrm{Na}$ alternativa $\mathbf{A}$ há a previsão de um valor que se destine à instituição para o gasto com as despesas gerais, bem como um valor destinado a despesas com manutenção dos imóveis.

Alternativa A:

Equação: Receita Potencial - Despesas Gerais da FUB - Manutenção = Receita Potencial Líquida

Em seguida, a Receita Potencial Líquida é dividida pela quantidade de servidores da FUB, docentes e técnicos administrativos. O resultado será objeto de análise para verificar se encontramos uma maneira de contemplar o benefício de 
moradia, que apenas $13 \%$ dos servidores recebem, para o máximo possível de servidores.

Equação: Receita Potencial Líquida / Quantidade de Servidores da FUB = Complemento de Renda

Ao analisar a receita de aluguel anual realizada pela FUB, em comparação com a receita de aluguel potencial nos exercícios de 2009 a 2013, verifica-se a sinalização de uma receita sacrificada:

Tabela 21: Receita sacrificada - Alternativa A

\begin{tabular}{|l|r|r|c|}
\hline \multicolumn{1}{|c|}{ Exercício } & Receita Efetiva $(\mathrm{R} \$)$ & Receita Potencial $(\mathrm{R} \$)$ & Receita Sacrificada \\
\hline 2009 & $27.700 .719,21$ & $53.430 .141,96$ & $193 \%$ \\
\hline 2010 & $34.214 .194,83$ & $53.970 .943,32$ & $158 \%$ \\
\hline 2011 & $32.193 .204,64$ & $61.345 .637,64$ & $191 \%$ \\
\hline 2012 & $36.853 .298,88$ & $61.462 .659,72$ & $167 \%$ \\
\hline 2013 & $39.828 .675,62$ & $64.707 .607,32$ & $162 \%$ \\
\hline Total & $170.790 .093,18$ & $294.916 .989,96$ & $173 \%$ \\
\hline
\end{tabular}

Fonte: SIAFI e SECOVI - DF, 2015

Elaborado pela autora

$\mathrm{Na}$ Tabela 22, foi demonstrada a distribuição do valor da Receita Potencial, expondo a possibilidade de destinação do saldo da potencial receita para complementar a renda da totalidade dos servidores. 
Tabela 22: Complemento de renda dos servidores da FUB - Alternativa A

$\mathrm{R} \$ 1,00$

\begin{tabular}{|c|c|c|c|c|c|c|c|}
\hline Ano & $\begin{array}{l}\text { Receita } \\
\text { potencial }\end{array}$ & $\begin{array}{c}\text { Despesas gerais } \\
\text { FUB }\end{array}$ & $\begin{array}{l}\text { Manutenção } \\
\text { Imóveis }\end{array}$ & $\begin{array}{l}\text { Receita potencial } \\
\text { líquida }\end{array}$ & $\begin{array}{c}\text { Quantidade } \\
\text { de } \\
\text { Servidores }\end{array}$ & $\begin{array}{c}\text { Complemento } \\
\text { de } \\
\text { renda por ano }\end{array}$ & $\begin{array}{l}\text { Complemento de } \\
\text { renda por mês }\end{array}$ \\
\hline 2009 & $53.430 .141,96$ & $21.990 .042,33$ & $5.710 .676,88$ & $25.729 .422,75$ & 5.504 & $4.674,68$ & 389,56 \\
\hline 2010 & $53.970 .943,32$ & 24.607.717,05 & $9.606 .477,78$ & $19.756 .748,49$ & 5.412 & $3.650,54$ & 304,21 \\
\hline 2011 & $61.353 .269,04$ & 27.092.716,09 & $5.100 .488,55$ & $29.160 .064,40$ & 5.319 & $5.482,25$ & 456,85 \\
\hline 2013 & $64.707 .607,32$ & 29.762.573,35 & $10.066 .102,27$ & $24.878 .931,70$ & 5.122 & $4.857,27$ & 404,77 \\
\hline \multicolumn{7}{|c|}{ Potencial valor de complemento da renda dos servidores da FUB (Média) } & 389,56 \\
\hline
\end{tabular}

Fonte: SIAFI e SECOVI - DF, 2015

Elaborado pela autora 
Da Receita Potencial de Aluguel dos cinco exercícios dividida pela quantidade de servidores, obteve-se o resultado do valor médio, nos cinco exercícios, de $\mathbf{R} \$$ 389,56, que, na Hipótese $A$, corresponde ao valor complementar da renda dos servidores da FUB.

Ao confrontar a média do aluguel adotado pela FUB e o valor médio de aluguel a preço de mercado, constatou-se que o subsídio médio recebido pelos servidores contemplados com o benefício de moradia é de $\mathbf{R} \mathbf{\$} \mathbf{1 . 1 8 7 , 0 2}$. Verifica-se que o valor subsidiado é maior que o valor da Hipótese $A$.

Tabela 23: Média do valor do subsídio aos servidores beneficiados

$\mathrm{R} \$ 1,00$

\begin{tabular}{|l|r|r|r|}
\hline \multicolumn{3}{|c|}{2009 a 2013 } \\
\hline Apartamento & Média Aluguel Efetivo. & Média Aluguel mercado & Subsídio \\
\hline 1 quarto & $3.079,80$ & $2.679,03$ & 400,77 \\
\hline 2 quartos & $1.580,55$ & $2.579,08$ & 998,53 \\
\hline 3 quartos & 964,55 & $3.256,34$ & $2.291,79$ \\
\hline 4 quartos & 960,44 & $4.389,34$ & $2.012,51$ \\
\hline \multicolumn{2}{|l|}{ Média do valor do subsídio } & & $1.187,02$ \\
\hline
\end{tabular}

Fonte: SIAFI e SECOVI - DF, 2015

Elaborado pela autora

Ao continuar a pesquisa, em busca de ampliar a possibilidade de alternativa do Custo de Oportunidade especificamente no sistema imobiliário da Fundação Universidade de Brasília, foi estudada a Alternativa B.

Alternativa B - A Fundação Universidade de Brasília vende os apartamentos e aplica no mercado financeiro, a baixo risco. A aplicação utilizada na análise é a poupança. Ressalta-se que a pesquisa não se atém à legalidade das vendas dos imóveis, apenas estuda alternativas para ampliação do benefício de moradia ao corpo funcional, baseadas em teorias econômicas.

Para desenvolver a pesquisa, consultamos os dados referentes ao valor do metro quadrado do imóvel para venda, retirada a informação do Boletim Imobiliário do SECOVI, emitido nos exercícios de 2010 a 2013.

A Receita Potencial de Venda dos apartamentos residenciais foi aferida pela multiplicação do metro quadrado dos imóveis da FUB com o valor de mercado do metro quadrado para venda, de imóveis residenciais e de imóveis comerciais, retirados do Boletim Imobiliário do SECOVI. 
$\mathrm{Na}$ alternativa $\mathrm{B}$, o valor resultante da venda dos imóveis é aplicado na poupança. Os índices utilizados nos estudos são extraídos do sítio do Banco Central do Brasil - Calculadora do Cidadão. O valor da venda dos imóveis foi lançado individualmente na calculadora, a cada ano, com a possibilidade de venda em cada exercício. Assim, os juros que incidem sobre o rendimento não são cumulativos. $O$ valor nominal foi preenchido com o valor da venda potencial de cada exercício, proveniente do valor corrigido da venda dos imóveis em períodos separados. Com a diferença entre o valor corrigido e o valor da venda, encontrou-se o Rendimento Anual.

Assim, na alternativa $B$, a receita dos imóveis da FUB é proveniente do Potencial Rendimento da Poupança, que é suficiente para arcar com as despesas gerais da instituição. Deve-se enfatizar que, nesse caso, a FUB não teria mais a despesa com manutenção dos imóveis, o que representaria um lucro adicional. Assim, o potencial

\section{Alternativa B:}

\section{Equação: Receita Potencial - Despesas Gerais da FUB = Receita Potencial Líquida}

Nesse estágio da alternativa $B$, ocorre também o processo de escolha, $O$ trade-off. A proposta é utilizar o rendimento mensal aplicado na poupança da seguinte forma:

1) Reservar $30 \%$ para a instituição, valor equivalente ao que a FUB recebe com o aluguel da política de moradia;

2) Reservar $70 \%$ do rendimento a serem divididos pela quantidade de servidores da FUB, docentes e técnicos administrativos. O objetivo da análise é verificar a possibilidade de ampliação do benefício de moradia para o máximo possível de servidores.

Equação: Receita Potencial Líquida / Quantidade de Servidores da FUB = Complemento de Renda

Alternativa B - Considerando o valor total de venda do último ano de nossa amostra, 2013, tem-se o valor de $R \$ 1.708 .475 .005,71$. Caso esse capital tivesse sido aplicado em 31/12/2013, em um ano teria gerado um rendimento de $\mathrm{R} \$$ 89.465.489,61 a uma taxa de juros de 5,2365700\% (a remuneração da poupança nesse período, segundo a calculadora do cidadão do site do Banco Central). 
Tabela 24: Rendimento da poupança

$\mathrm{R} \$ 1,00$

\begin{tabular}{|c|r|r|r|r|}
\hline Ano & \multicolumn{1}{|c|}{ Valor de Venda } & Índice acum. & \multicolumn{1}{c|}{ Valor corrigido } & \multicolumn{1}{c|}{ Rendimento anual } \\
\hline 2009 & $1.348 .701 .557,97$ & 1,06 & $1.434 .097 .564,26$ & $85.396 .006,29$ \\
\hline 2010 & $1.359 .221 .828,79$ & 1,06 & $1.443 .738 .378,03$ & $84.516 .549,24$ \\
\hline 2011 & $1.480 .079 .441,74$ & 1,07 & $1.580 .955 .588,16$ & $100.876 .146,42$ \\
\hline 2012 & $1.629 .240 .887,11$ & 1,02 & $1.665 .660 .286,20$ & $91.646 .031,54$ \\
\hline 2013 & $1.708 .475 .005,71$ & 1,05 & $1.797 .940 .495,32$ & $89.465 .489,61$ \\
\hline
\end{tabular}

Fonte: SECOVI-DF e Calculadora do Cidadão - Banco Central, 2015

Elaborado pela autora

$\mathrm{Na}$ Tabela 25, está esmiuçada a distribuição do rendimento anual da poupança, deduzido do valor das despesas gerais e do valor da despesa de manutenção da FUB nos cinco exercícios. A Potencial Receita Líquida do Rendimento anual da Poupança é dividida pelo número de servidores da FUB. $\mathrm{O}$ resultado é um potencial complemento de renda no valor de $\mathbf{R} \mathbf{8 8 1 , 0 9}$. Verifica-se que o valor de complemento de renda da Hipótese $B$ também é menor que o valor subsidiado, $\mathbf{R} \$ \mathbf{1 . 1 8 7 , 0 2 .}$

O complemento da renda ao corpo funcional, proposto nas alternativas $A$ e $B$ é com base na média da receita de aluguel potencial e na média do potencial rendimento de poupança. Sendo os salários dos servidores diferenciados, o valor médio do complemento de renda atenderá um número maior de docentes e técnicos. O servidor que recebe um salário menor terá um benefício proporcionalmente maior. Ao passo que o servidor que tenha uma renda maior terá um benefício proporcionalmente menor. A distribuição do complemento de renda, como valor médio fixo, é uma situação de equidade e um critério de justiça. Conforme afirma John Rawls o conceito de justiça "se refere a um equilíbrio apropriado entre exigências conflitantes". A partir desse princípio de justiça que John Rawls afirma ser capaz de oferecer uma concepção que determine o equilíbrio. O conceito de justiça se aplica sempre que há distribuição de algo que se considere vantajoso ou desvantajoso e a identificação dos princípios de justiça é o meio pelo qual se torna possível determinar o equilíbrio inerente a esse conceito. (BRANDO, 2012) 
Tabela 25: Valor de complemento de renda dos servidores da FUB - Alternativa B

$\mathrm{R} \$ 1,00$

\begin{tabular}{|c|c|c|c|c|c|c|c|}
\hline Ano & $\begin{array}{c}\text { Potencial } \\
\text { rendimento anual }\end{array}$ & $\begin{array}{l}\text { Despesas } \\
\text { gerais }\end{array}$ & $\begin{array}{c}\text { Despesas } \\
\text { com } \\
\text { manutenção }\end{array}$ & $\begin{array}{l}\text { Potencial receita } \\
\text { líquida }\end{array}$ & $\begin{array}{l}\text { Quantidade de } \\
\text { servidores }\end{array}$ & $\begin{array}{l}\text { Complemento de } \\
\text { renda ao ano }\end{array}$ & $\begin{array}{l}\text { Complemento de } \\
\text { renda ao mês }\end{array}$ \\
\hline 2009 & $85.396 .006,29$ & $21.990 .042,33$ & $5.710 .676,88$ & $57.695 .287,08$ & 5504 & $10.482,43$ & 873,54 \\
\hline 2010 & $84.516 .549,24$ & $24.607 .717,05$ & $9.606 .477,78$ & $50.302 .354,41$ & 5412 & $9.294,60$ & 774,55 \\
\hline 2011 & $100.876 .146,42$ & 27.092.716,09 & $5.100 .488,55$ & $68.682 .941,78$ & 5319 & $12.912,75$ & $1.076,06$ \\
\hline 2013 & $89.465 .489,61$ & $29.762 .573,35$ & 10.066.102,27 & 49.636.813,99 & 5122 & $9.690,90$ & 807,58 \\
\hline \multicolumn{7}{|c|}{ Potencial valor complementar da renda dos servidores da FUB (Média) } & 881,09 \\
\hline
\end{tabular}

Fonte: SGP, SECOVI-DF e Calculadora do Cidadão - Banco Central, 2015.

Elaborada pela autora 
Figura 15: Potencial receita de rendimento da poupança em relação a receita de aluguel realizada

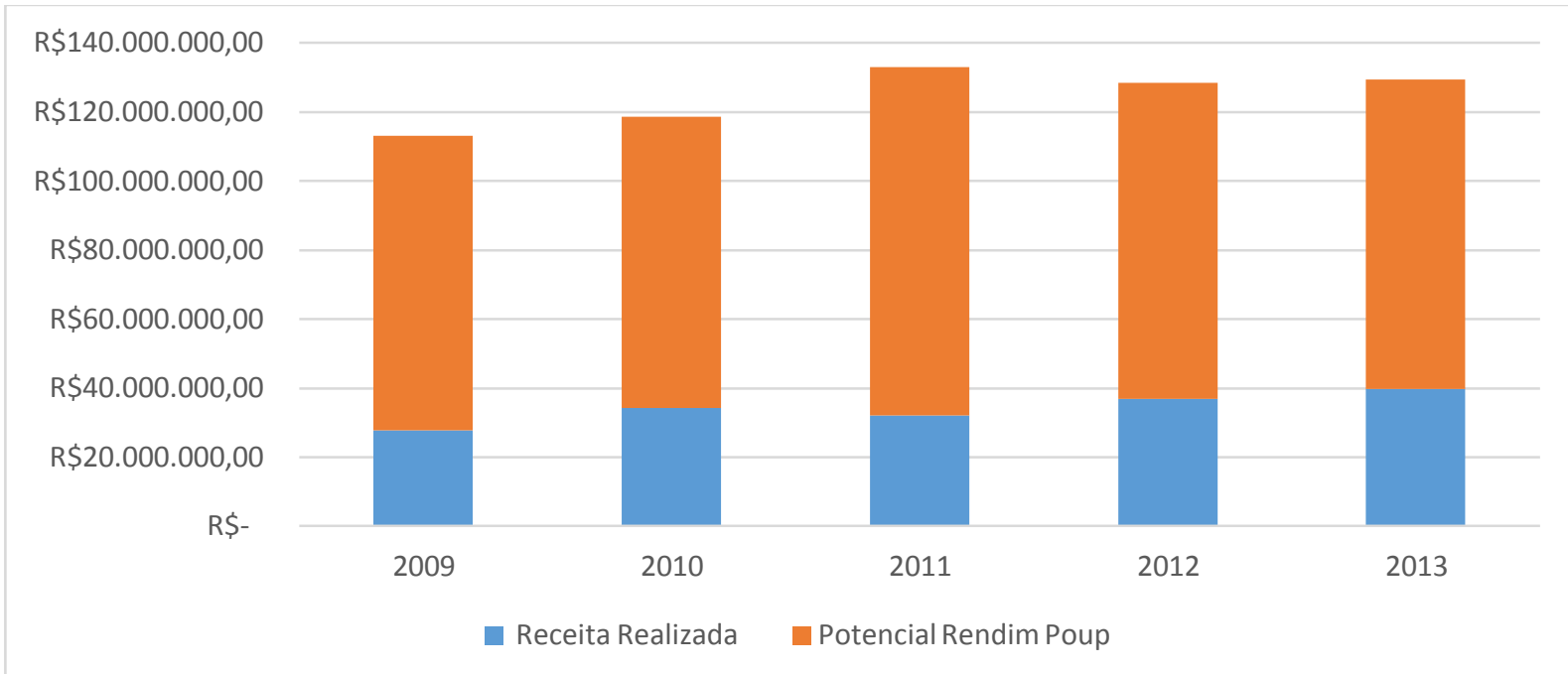

Fonte: SIAFI, SECOVI-DF e Calculadora do Cidadão - Banco Central, 2015. Elaborada pela autora

Verifica-se ao analisar a figura 15 que a Fundação Universidade de Brasília, mantem os valores de aluguel abaixo do valor de mercado, proporciona subsídio de aluguel a uma pequena parcela de servidores, e ainda arca com alto valor de manutenção dos imóveis.

Figura 16: Representatividade do potencial rendimento da poupança em relação ao orçamento da FUB

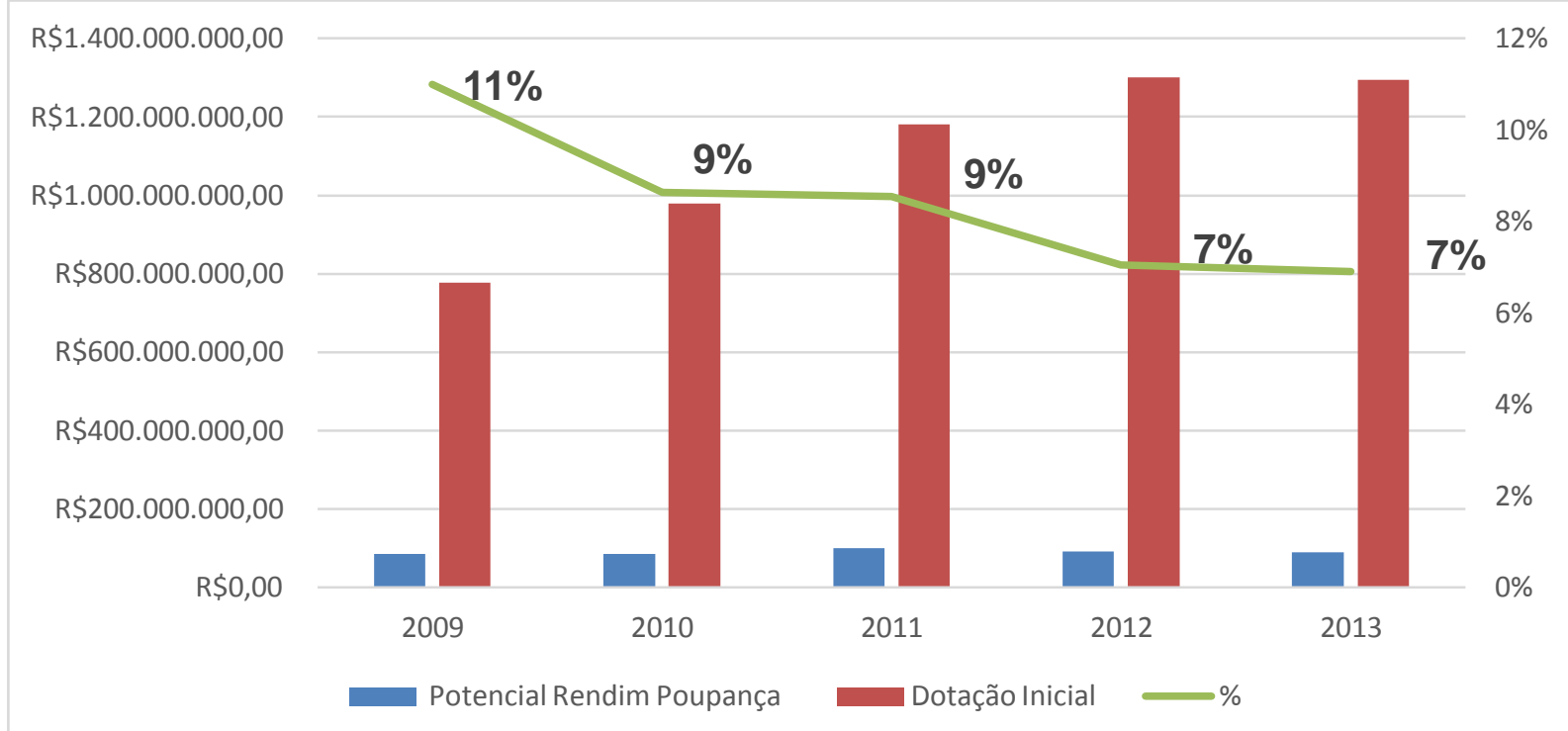

Fonte: SGP, SECOVI-DF e Siga Brasil - Senado Federal, 2015.

Elaborada pela autora

Observa-se que a receita potencial de rendimento da poupança é em média $8 \%$ da dotação inicial da FUB, mais representativa que a receita realizada 
apresentando $2 \%$ da dotação inicial.

Tabela 26: Receita sacrificada em comparação ao potencial rendimento da poupança

\begin{tabular}{|c|c|c|c|}
\hline Exercício & Receita realizada & Potencial rendimento da poupança & Receita Sacrificada \\
\hline 2009 & $27.700 .719,21$ & $85.396 .006,29$ & $308 \%$ \\
\hline 2010 & $34.214 .194,83$ & $84.516 .549,24$ & $247 \%$ \\
\hline 2011 & $32.193 .204,64$ & $100.876 .146,42$ & $313 \%$ \\
\hline 2012 & $36.853 .298,88$ & $91.646 .031,54$ & $249 \%$ \\
\hline 2013 & $39.828 .675,62$ & $89.465 .489,61$ & $225 \%$ \\
\hline Total & $170.790 .093,18$ & $451.900 .223,10$ & $265 \%$ \\
\hline
\end{tabular}

Fonte: SIAFI, SECOVI-DF e Calculadora do Cidadão - Banco Central, 2015

Elaborada pela autora

Verifica-se, ao analisar a Tabela 26, que a Hipótese B aumentaria em média $268 \%$ a receita da Fundação Universidade de Brasília.

Ao comparar os potenciais valores que poderiam complementar o salário do corpo funcional da FUB, verificamos que, na Hipótese $A$, no caso de o valor de aluguel adotado para os imóveis ser o de mercado, o complemento da renda seria em média de $R \$ 389,56$. Na Hipótese $B$, no caso de os imóveis da FUB serem vendidos, o complemento na renda dos servidores seria em média de $R \$ 881,09$. O valor do subsídio médio recebido hoje pela pequena parcela de servidores é de $\mathrm{R} \$$ 1.187,02. Observa-se que os valores encontrados nas Hipóteses A e B são inferiores ao valor subsidiado. No entanto, a primordial diferença é que as hipóteses estudadas trazem resultados que podem ser benéficos para todo o corpo funcional da FUB.

Ao mesmo tempo em que o Sistema Imobiliário vigente beneficia poucos, não há uma norma que estabeleça limitação de tempo de ocupação dos imóveis, motivo pelo qual grande número de servidores beneficiados desocupa o apartamento apenas quando se aposenta ou falece, o que diminui a possibilidade de outro servidor ser beneficiado. $O$ resultado é uma grande quantidade de inscritos para moradia e poucos apartamentos vagos disponíveis. 
Figura 17: Percentual de servidores contemplados com o benefício

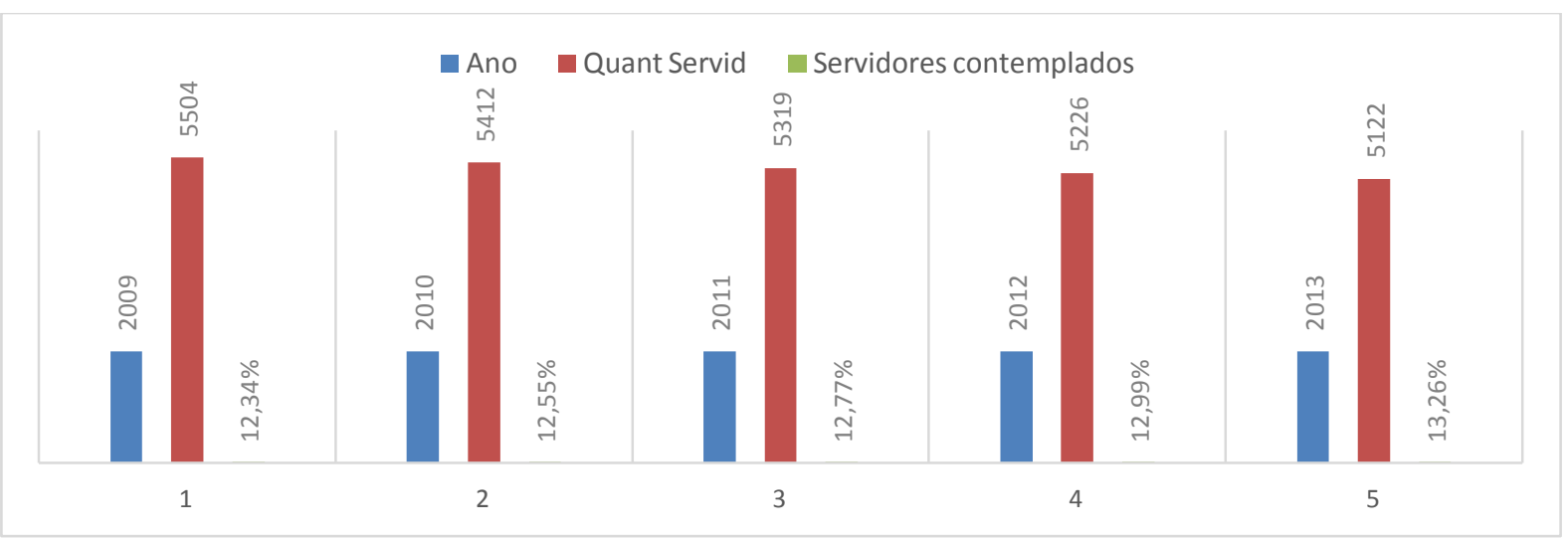

Fonte: SIAPE, 13/5/2015.

Elaborada pela autora

A figura 18 expõe o percentual de servidores beneficiados com o subsídio de moradia no período de cinco exercícios:

Figura 18: Quantidade de servidores subsidiados e não-subsidiados

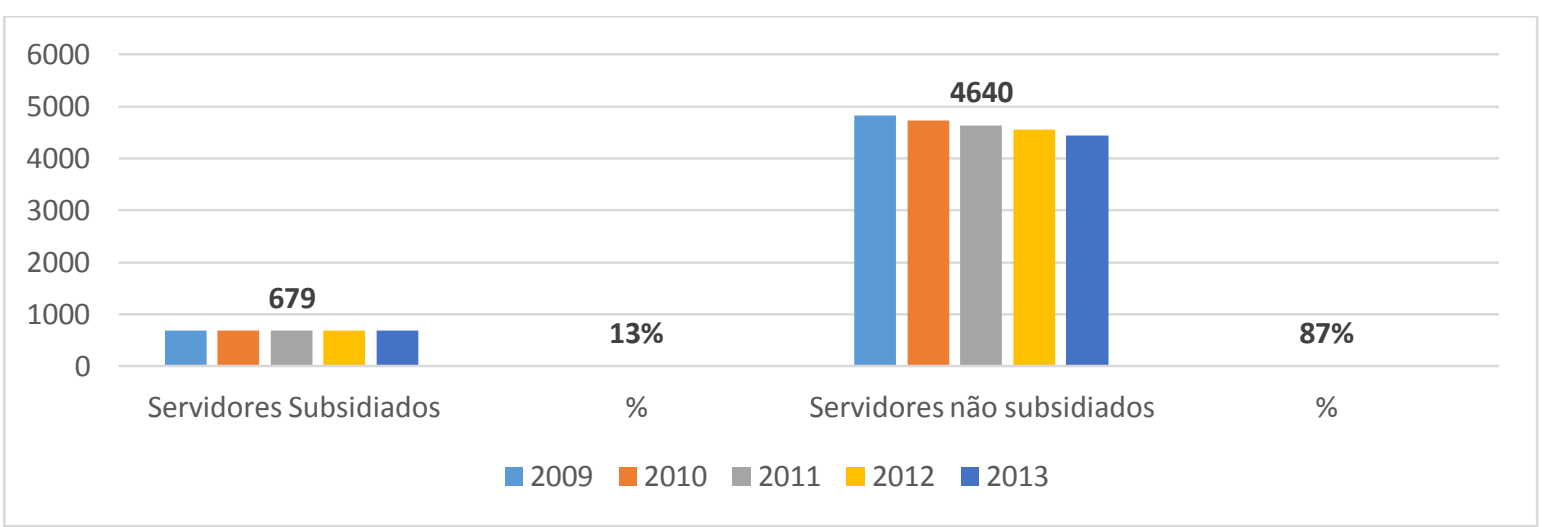

Fonte: SIAPE e Secretaria de Gestão Patrimonial - SGP, 2015.

Elaborada pela autora

Na figura 18 , fica evidenciado que $87 \%$ dos servidores não são contemplados com o benefício de moradia e apenas $13 \%$ o obtêm. 


\section{CONCLUSÃO}

Este trabalho teve como objetivo geral avaliar a contribuição econômicofinanceira do Sistema Imobiliário da FUB para a Universidade. Para isso, foram definidos como objetivos específicos: levantar o valor de aluguel pago por cada unidade para descobrir a receita atual; levantar o valor de mercado de cada unidade (metro quadrado); verificar quanto a FUB teria que receber em relação a dívidas com inadimplentes; identificar quanto a instituição gasta com manutenção e reformas de infraestrutura nos imóveis para mantê-los em condições de uso; identificar também a representatividade das despesas das atividades imobiliárias em relação ao orçamento da FUB; apresentar a receita resultante das atividades imobiliárias com as despesas de manutenção dos imóveis; apresentar o custo de oportunidade aplicado à FUB.

Para atingir esses objetivos, buscou-se um levantamento histórico da instituição, a fundamentação dos dados junto ao setor responsável pelos imóveis, conhecer o Sindicato de Habitação do DF e os documentos emitidos por ele. Buscou-se embasamento na teoria de Pareto, na economia Positiva e Normativa, na teoria da Economicidade, da Eficiência e da teoria do Custo de Oportunidade. Posteriormente, foi desenvolvido um estudo de caso na Fundação Universidade de Brasília. Em relação às principais estratégias, optou-se por acompanhar as atividades de monitoramento de locação e venda no mercado, observar opiniões de servidores sobre o tema do trabalho, entender a situação dos servidores beneficiados e não beneficiados.

A principal motivação é poder ampliar o benefício a todos os servidores de forma justa, igualitária, sem prejudicar demasiadamente aqueles que já são beneficiados.

Observou-se, com base nos dados apresentados, que, caso a Fundação Universidade de Brasília resolvesse adotar uma política alternativa de alocação de recurso, isso envolveria um possível prejuízo a alguns indivíduos. Nesse sentido, a situação atual é um ótimo de Pareto.

No entanto, as alternativas $A$ e $B$ propostas no trabalho, se ajustam ao critério de Kaldor-Hicks, quando diz: se os benefícios forem maiores que os custos, essa linha de ação deve ser lavada adiante, mesmo que alguns sejam perdedores e 
outros ganhadores. Considerando que os benefícios aos ganhadores impliquem em um montante tal que seja possível, ao menos em tese, a compensação da redução do bem-estar dos perdedores. Nas alternativas de gestão imobiliária apresentadas podem trazer benefícios maiores que os custos à comunidade da UnB. Além de ser uma questão de equidade. O valor médio do complemento de renda proporcionará um benefício proporcionalmente maior ao servidor que recebe menor salário. 0 servidor que ganha mais receberá o benefício proporcionalmente menor.

Portanto, do ponto de vista de eficiência, dada a dotação atual dos indivíduos envolvidos, isto é, os detentores de direitos de aluguel e os que não têm esses direitos, essa seria a melhor configuração. Entretanto, do ponto de vista normativo, deve-se questionar se tal situação (e dotação) está alinhada com os interesses maiores da universidade.

A situação vigente nos remete à Resolução 30/2004, do Conselho Diretor, dispondo que a finalidade dos imóveis residenciais da FUB é atração e fixação de quadros diferenciados de servidores docentes e de técnicos administrativos. No entanto, $71 \%$ dos imóveis residenciais da FUB está ocupado por terceiros.

Outro ponto conflitante, no que diz respeito ao recurso público, foi a manutenção do valor da taxa de ocupação dos 679 apartamentos durante 17 anos. Tal circunstância perdurou ao longo de várias administrações da UnB e demonstrou despreocupação com o impacto financeiro deficitário que a FUB assumiria no período de duas décadas. Expôs também o uso do recurso público em benefício de uma pequena parcela de servidores contemplados com pagamento de taxa de ocupação subsidiada e inalterada por 17 anos.

Políticas públicas, como as de moradia, devem alcançar um objetivo ou satisfazer uma missão, que não parecem claros na política atual frente às mudanças no quadro de funcionários que a universidade sofreu ao longo dos anos.

No início, tal política talvez fosse capaz de atender praticamente à totalidade da comunidade. Nesse contexto, um critério de universalidade talvez fosse facilmente alcançável.

Hoje, com escassez de recursos, é necessário repensar tais critérios, levando em consideração o interesse final da universidade como um todo, e esclarecer o objetivo final de tal política. Trata-se de uma política puramente de habitação, tratase de subsídio de moradia à comunidade, de uma política de atração de profissionais altamente qualificados ou de algum critério alternativo. Dependendo do 
objetivo final que a universidade desejar alcançar, o arranjo provavelmente será diferente.

Portanto, deve ser considerado o objetivo de avaliar a contribuição econômico-financeira do Sistema Imobiliário da FUB para a Universidade, na ótica de uma alternativa que o sistema imobiliário pudesse oferecer um benefício pecuniário para cada indivíduo servidor da instituição. A ação alternativa atingiria a totalidade dos servidores e, com isso, promoveria a contribuição econômica e financeira para a Universidade de forma expressiva.

Percebe-se que a pesquisa vem no sentido de demonstrar à Administração da Universidade uma visão de perspectiva de futuro com o sistema imobiliário da FUB. Faz-se necessária a interação de alternativas possíveis que signifiquem um processo de decisão estratégica, a fim de a instituição alcance formas economicamente positivas para que prosperem os recursos advindos de receitas dos bens.

A presente análise conclui que as possibilidades $\mathbf{A}$ e $\mathbf{B}$ desenvolvidas na pesquisa inovariam a instrumentalização dos recursos. A instituição utilizaria 0 patrimônio para robustecer os recursos próprios de maneira alternativa, inovadora e com equidade. Seria uma demonstração de eficiência e imparcialidade ao utilizar os recursos próprios da FUB em benefício da própria Universidade e de seus servidores. Poder oferecer uma renda complementar para a totalidade de seus servidores, destinar parte do recurso para despesa de manutenção dos imóveis, bem como para despesas gerais da universidade, é legitimar a presença da Universidade de Brasília no país como um exemplo de aplicação eficiente e equânime de seus recursos. O principal ganho foi verificar a possibilidade de aplicação de uma alternativa além da política de moradia existente. É uma ação desejada, mas com vários desafios.

Sugerimos a continuação do estudo, aplicando questionários para identificar as reais opiniões da comunidade e da Administração.

A pesquisa teve limitações no sentido de conseguir dados confiáveis pela Secretaria de Gestão Patrimonial, pois, devido à falta de automatização de alguns processos na gestão do patrimônio, há a possibilidade de haver erros em alguns dados. O sistema utilizado para controles dos dados imobiliários da FUB é o mesmo criado em 1998. 


\section{REFERÊNCIAS}

BATISTA JÚNIOR, O. A. Princípio constitucional da eficiência administrativa. Belo Horizonte: Mandamentos, 776 p., 2004.

BONACIM, Carlos; CUNHA, Júlio; GONÇALVES, Eduardo. Uma avaliação da aplicação do conceito de custo de oportunidade no varejo: o caso de uma loja de materiais de construção. São Paulo: Revista Científica da Fundação Educacional de Ituverava -Nucleus, v.5, n.2, out. 2008.

BONATES, M. F.; VALENÇA, M. M. Vilas militares no Brasil. Gestão, política de locação e desenvolvimento urbano. São Paulo: Arquitextos, ano 11, n. 125.09, Vitruvius, out. 2010. Disponível em: <http://www. vitruvius. com. br/ revistas/read /arquitextos/11.125/3570>. Acesso em: 5 maio. 2014.

BRANDO, Marcelo, A crítica da vertente econômica à teoria da justiça de John Rawls. Rio de Janeiro: Revista Quaestio luri, v.5, n.2, ISSN 1516-0351 p. 1-32. 2012. Disponível: < http:// www. e-publicacoes .uerj. br/index. php/ quaestioiuris larticle/ view /9871 > Acesso em 20/8/2015.

BRASIL. Lei 4.320 comentada [por] J. Teixeira Machado Jr. [e] Heraldo da cas Reis. 26.ed. rev. atual. Rio de Janeiro, IBAM, 1995. 380p.

BRASIL. Decreto Lei 200, de 25 de fevereiro de 1967. Dispõe sobre a organização da Administração Federal, estabelece diretrizes para a Reforma Administrativa e dá outras providências.

Disponível em: http://www2.camara.leg.br/legin/fed/declei/1960-1969/ decreto-lei-200-25-fevereiro1967 -376033 -norma -pe.html > Acesso em: 15 mai. 2014.

BRASIL. Lei de Responsabilidade Fiscal, Lei Complementar 101, de 4 de maio de 2.000. Estabelece normas de finanças públicas voltadas para a responsabilidade na gestão fiscal e dá outras providências. Disponível em: < http://presrepublica.jusbrasil. com.br/legislacao/102628/lei-de-responsabilidade-fiscal-lei-complementar-101-00> Acesso em 15 mai. 2014.

BUGARIN, P. S. O Princípio Constitucional da Economicidade na Jurisprudência do Tribunal de Contas da União. Belo Horizonte: Fórum, 2004.

BURCH, E.E.; HENRY, W.R. "Opportunity and Incremental Cost; Attempt to Define in Systems Terms: A Comment". The Acounting Review, v. 49, n. 1, pp.118-123 jan. 1974. Amerincan Accounting Association. Disponível em: $<$ http://www. jstor. org /stable /244804?seq=1\# page scan tab contents. Acesso em: 7 mai. 2015.

CAIDEN, N. J.; CAIDEN, G. E. Enfoques e lineamientos para el seguimiento, la meidción y la evaluación del desempeõ em programas del sector público. Brasília: Revista do Serviço Público, v. 52 n.1, jun-mar/2001. Escola Nacional da 
Administração Pública. Disponível em:< http://seer.enap.gov.br/index.php/RSP/ article /view/301/307>. Acesso: 6 jun. 2014.

DI PIETRO, M. Direito Administrativo, São Paulo: Atlas, 2005.

DIAS FILHO, J. M.; MACHADO, L. H. B. Abordagens da pesquisa em contabilidade. In: IUDÍCIBUS, S.; LOPES, A. B. (coords.). Teoria Avançada da Contabilidade. São Paulo: Atlas, 2004.

FARIA, J. H. de. Gestão participativa: relações de poder e de trabalho nas organizações. São Paulo: Atlas, 2009, p. 39.

FIORENTINI, D.; LORENZATO, S. Investigação em educação matemática: percursos teóricos e metodológicos. 2ed. Campinas: Autores Associados, 2009. $240 \mathrm{p}$.

FRIEDMAN, Milton. A metodologia da economia positiva. Edições Multiplic, 1, n. 3, p.163-200, fev. 1981.

GEOFFROY, Ricardo. Eficiências econômicas em atos de concentração: rumo à incorporação das eficiências dinâmicas. (Conclusão do curso de Mestrado em Ciências Econômicas) - Instituto de Economia. Universidade Estadual de Campinas, 2010.

GREMAULD, A.P. et al. Manual de Economia. 4a Edição. Editora Saraiva. São Paulo. 2004.

HOERETH, J. K.; PACKNETT, D.; PERRY, D. C. University Employer-Assisted Housing: Models of University-Community Partnerships. () 2007 Lincoln Institute of Land Policy and the Great Cities Institute (GCl) at University of Illinois at Chicago.

IUDÍCIBUS, S. de; MARTINS, E.; CARVALHO, N. L. Contabilidade: aspectos relevantes da epopéia de sua evolução. Revista de Contabilidade e Finanças, São Paulo, v. 2, n. 38, p. 7-19, 2005.

LAMPARD, E. E. The history of cities in the economically advanced areas. Economic Development and Cultural Change, 1955. Disponivel em: https://books.google.com.br/books. Acesso: 31 ago. 2014.

LEMOS, Alan. Falhas de mercado, intervenção governamental e a teoria econômica do Direito. Disponível em: https://ri.ufs. br/bitstream /123456789/651/1/ FalhasMercadolntervencao.pdf, . Acesso em: 20 ago. 2015.

LIPSEY, R. G. Introdução à Economia Positiva. Martins Fontes. 1르. Ed. São Paulo.1986.

MANKIW, N. G. Introdução à economia/ M. Gregory Mankiw; [tradução Allan Vidigal Hastings] - São Paulo: Cengage Learning, 2009. 
MARTINS, Eliseu. Contabilidade de Custos. São Paulo: Atlas, 1995.

MEIRELLES, H. L. Direito Administrativo Brasileiro, 32. ed. - São Paulo: Malheiros, 2006.

NIED, P. S. O conceito de eficiência econômica e a ruptura do contrato de sociedade. In: XXI Encontro Nacional do CONPEDI, 2012, Uberlândia. Anais do XXI Encontro Nacional do CONPEDI. Florianópolis: Fundação Boiteux, 2012.

PEREIRA, A.; Souza B.; REDAELLI, D.; IMONIAN, J. Custo de oportunidade: conceitos e contabilização. Programa Multiinstitucional e Inter-Regional de PósGraduação em Ciências Contábeis, Brasília: UnB/UFPB/UFRN, 2009.

SILVA, J. A. da. Curso de Direito Constitucional Positivo. 22.ed. São Paulo: Malheiros, 2002.

UNIVERSIDADE DE BRASÍLIA. Relatório da I Audiência sobre Política de Moradia da UnB. Brasília, 2013. 21p.

VERHOEF, E. T.; NIJKAMP, P. Externalities in the Urban Economy. Tinbergen Institute Discussion Papers 03-078/3, Tinbergen Institute, 2003. Disponível em <http://papers.tinbergen.nl/03078.pdf>: Acesso: 5 ago. 2015.

VELLOSO, J.; MARQUES, P.M.F. Recursos próprios da UnB, o financiamento das IFES e a reforma da educação superior. Educ. Soc., Campinas, vol. 26, n. 91, p. 655-680, mai/ago. 2005. Disponível em:<http:www.cedes.unicamp.br> Acesso: 15 jun. 2014.

VILLAÇA, Flávio. Espaço Intra-Urbano no Brasil. São Paulo: Studio Nobel, 1aㅗ edição, 2001. 